\title{
How to Evaluate the Performance of the Taiwan Biotech and Biopharmaceutical Corporations?
}

\author{
Tzu-Chun Sheng ${ }^{1}$ \\ ${ }^{1}$ Department of Finance, Ling Tung University, Taiwan, R. O. C. \\ Correspondence: Tzu-Chun Sheng, Department of Finance, Ling Tung University, Taichung City, Taiwan, R. O. \\ C. Tel: 886-989-997-776. E-mail: morgan1125@teamail.ltu.edu.tw
}

Received: July 30, 2015

Accepted: September 6, 2015

Online Published: September 25, 2015

doi:10.5539/ibr.v8n10p1

URL: http://dx.doi.org/10.5539/ibr.v8n10p1

\begin{abstract}
Modern biotechnology and pharmaceutical industry, the most developmental mainstream, has been generally acknowledged in the $21^{\text {st }}$ century. The approach of this study surmounted the traditional DEA and SFA, combining with modified Delphi approach, ISM, FANP and performance evaluation table to build evaluation mode of operating performance precisely and completely in Taiwan biotech and pharmaceutical corporations. Considering 4 criteria and 18 sub-criteria complied to evaluate the operating performance in the enterprise. The analyzed result appeared, the significance of criteria is "Product and technology R\&D", "Financial performance", "Production and quality management" and "Organization characteristics and operation management" in sequence. The top 5 key sub-criteria influence the evaluation of operating performance in Taiwan biotech and pharmaceutical corporations are "Profitability", "Efficiency of production and cost", "Innovative products and R\&D strategies", "Quality management and cost control" and "Operation strategy and business mode". The last 5 key sub-criteria are "Human resources management", "Project management", "Innovation of process technology", "Competence of financial operation" and "Market share". Finally, the top 10 of conglomerate revenue in listed companies taken as the sample of empirical research on this study. According to the experts' evaluation, the total point of weighted average is $\mathbf{5 8 . 9 0 2 0}$ of whole sample in complete period in all enterprises, which fell at the grade of 'Slightly good' as a whole. The related results accord with the real situation in the industry. The result of this study is able to be a significant basis as the policies drawn up by government, operating performance evaluated by the enterprise and investment target measured by the investors.
\end{abstract}

Keywords: corporation performance evaluation, fuzzy analytic network process, interpretive structural model, modified Delphi approach, performance evaluation table, Taiwan biotech and biopharmaceutical industry

\section{Introduction}

Modern biotechnology and pharmaceutical industry have combined with the multi-cross-fields such as the molecular biology, microbiology, gene engineering, electrical engineering, the mechanical engineering and so on as the research results in twenty years recently. Originally, the extensive application of biotechnology is so as to provide stable food supply in human society as well as enhance people's quality of life. With the constant breakthrough, biotechnology has been extensively applied to a plenty of industries as the research and development of pharmaceuticals, health care medicine, environmental protection, food science and technology, material science and the explosion of new energies...etc. New founded corporations of biotechnology and pharmaceuticals, for example, Amgen, Biogen, Genentech, and Hybritech, redesigned and composed the products with gene proteins as the research objective to initiate the new aspect of modern biological science and technology and pharmaceutical industry in the early of 80 's. Human genome project (HGP) was facilitated to complete the drawing of human genome map by the USA and the UK in 2003. The science field strode a big step forward the interpretation and analysis of biology and gene from then on.

Currently, the governments in most of advanced countries value the investments and developments in biology technology and pharmaceutical industry with prudent attitude. Furthermore, these governments invest huge resources in such emerging industry to bring in enormous profits. Consequently, biotech and biopharmaceutical industry are not only generally acknowledged as the mainstream with a highly potential in the $21^{\text {st }}$ century, but the industry of facilitating the quality of life for humankind. A number of global nations incorporate the industry of biotechnology with national key industry as future developed project, founding the policies as centralized 
resources, positive investments and advanced developments. The rate has gone up 8.7\%, compared the US\$79.73 billion in 2013 with US\$73.34 billion in 2012, in light of statistics by BioCentury. In 2013, 59 biotechnology corporations issued initial public offering (IPO) successfully, which is more 34 corporations than 2012, hit the high record recently. Besides, the market of biotechnology pharmaceutical is the most high-profile industry of all. The research report indicated the growth rate of global medicine market will be up to 5 7\% in 2017 from 2 3\% in 2017 by IMS Health. The global market scale of medicine will reach to US $\$ 1.2$ trillion as well as the compound annual growth rate (CAGR) is approximately 5.3\%.

The definition and scope of biotechnology among different governments and institutions has dissimilar views. Convention on Biological Diversity (CBD) defined 'Biotechnology' as any technological application that uses biological systems, living organisms, or derivatives thereof, to make or modify products or processes for specific use. Organization for Economic Cooperation and Development (OECD) clarified the application of science and technology to living organisms as well as parts, products and models thereof, to alter living or non-living materials for the production of knowledge, goods and services, which differentiates from the development of conventional biology, moreover, the development of biotech and biopharmaceutical industry focuses on the disciplines as proteomics, comparative genomics, pharmacogenomics, metabolomics, translational medicine, bioinformatics, systems biology, synthetic biology and so on.

Taiwanese government initiated to implement a series of policies and bills in order to construct an excellent investing environment for biotechnological industry in 1980. Therefore, Taiwanese government also successively promulgated Action Plan for Biotechnology Industry, Taiwan Diamond Action Plan for Biotech Takeoff and Development Program of Industrialization for Agricultural Biotechnology. In 2013, Taiwan Biotechnology Industrialization Take-off Action Plan was approved and verified to facilitate the medicine, medical equipment and health care management service to fulfill the industrialized development, making successful cases continuously. As Figure 1 indicated, Taiwanese government split biotech and biopharmaceutical industry into three sectors: Applied biotechnology sector, pharmaceutical sector and medical device sector. These endeavors were struggled to reinforce the infrastructure of biopharmaceutical Industry, provide a well-developed environment, strengthen industrialized functions and accelerate the biopharmaceutical industry to the mainstream in the future by Taiwanese government.

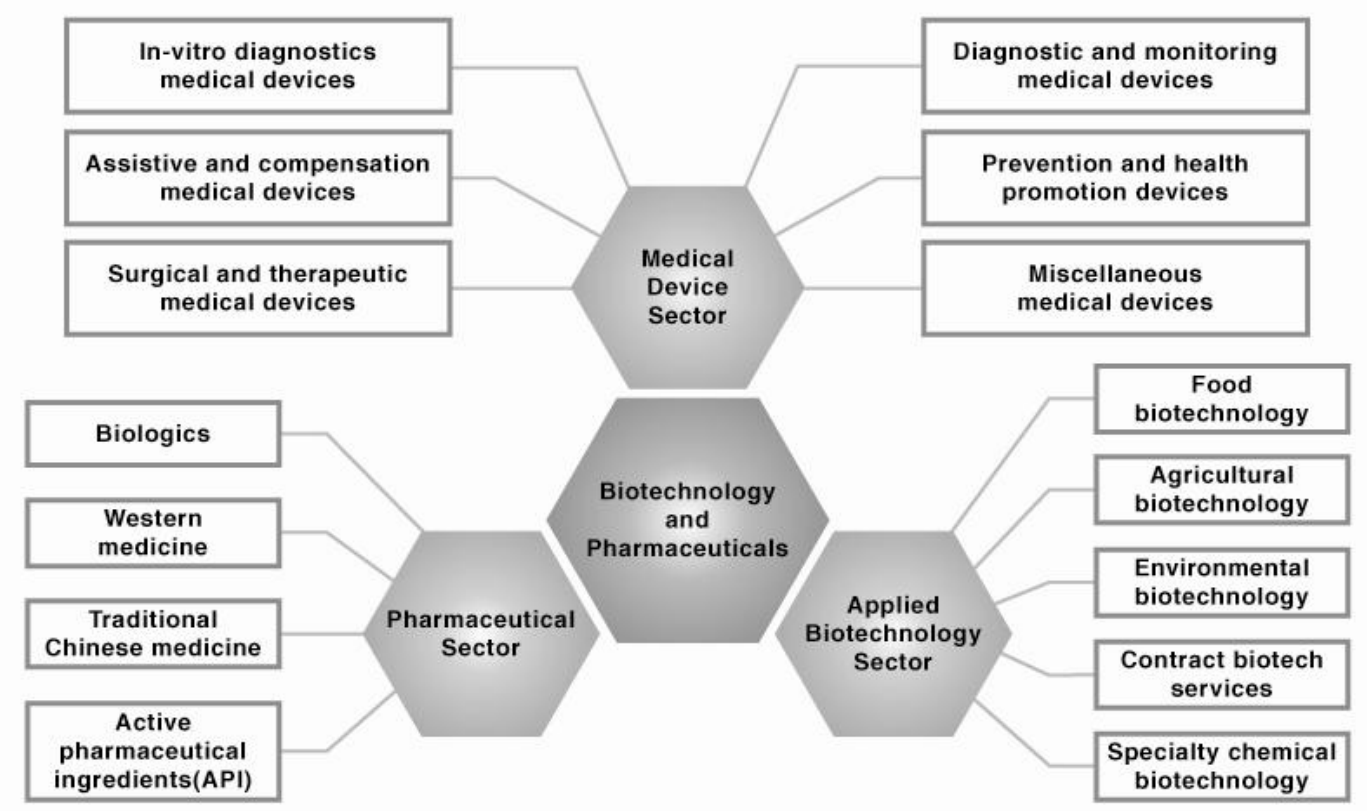

Figure 1. Taiwan biotech and biopharmaceutical industry sectors

After going through years of efforts among Taiwanese government, academia and industrial circle, the value of production among Taiwanese biotech, pharmaceutical industry and three big fields has been shown as the 
successive growth for 12 years from 2002 through 2013. Up to 2013, the revenue of integral biotech industry has excessed US $\$ 9.3$ million, the growth rate of which increased 5\%, compared with 2013. The number of manufactures of biotech came to 1601 in 2012, the numbers of listed companies of at stock exchange market and at over-the counter market of which reached 83 incorporations with 71580 employees. In addition, the industry value of import and export has been increasing continuously. As Table 1 indicated the statistical figures of scale among Taiwanese biotech and biopharmaceutical industry and three fields, revenue, the value of import and export and market demands from 2011 to 2013.

Table 1. 2011-2013 Status of Taiwan's biotechnology and pharmaceutical industries

\begin{tabular}{|c|c|c|c|c|c|c|c|c|c|c|c|c|}
\hline \multirow{2}{*}{$\begin{array}{l}\text { Industry Type } \\
\text { Year }\end{array}$} & \multicolumn{3}{|c|}{ Applied Biotechnology } & \multicolumn{3}{|c|}{ Pharmaceuticals } & \multicolumn{3}{|c|}{ Medical Device } & \multicolumn{3}{|l|}{ Total } \\
\hline & 2011 & 2012 & 2013 & 2011 & 2012 & 2013 & 2011 & 2012 & 2013 & 2011 & 2012 & 2013 \\
\hline Revenues & 2186 & 2492 & 2627 & 2408 & 2701 & 2768 & 3235 & 3687 & 3927 & 7829 & 8881 & 9301 \\
\hline No. of companies & 402 & 450 & 490 & 400 & 350 & 350 & 626 & 705 & 761 & 1428 & 1505 & 1601 \\
\hline Personnel & 15780 & 16770 & 17540 & 19332 & 18500 & 19000 & 30250 & 34200 & 35040 & 65362 & 69470 & 71580 \\
\hline Export value & 880 & 952 & 1004 & 518 & 655 & 658 & 1336 & 1553 & 1626 & 2740 & 3161 & 3289 \\
\hline Import value & 1424 & 1621 & 1884 & 2792 & 3319 & 3332 & 1792 & 1932 & 2032 & 6011 & 6872 & 7027 \\
\hline Import export & 60:40 & $62: 38$ & $62: 38$ & $78: 22$ & $76: 24$ & $76: 24$ & $59: 41$ & $58: 42$ & $58: 42$ & $65: 35$ & $64: 36$ & $65: 35$ \\
\hline $\begin{array}{l}\text { Domestic market } \\
\text { demand }\end{array}$ & 2730 & 3161 & 3285 & 4682 & 5366 & 5442 & 3691 & 4066 & 4313 & 11100 & 12592 & 13040 \\
\hline
\end{tabular}

Note. Unit: US\$ million.

Biotech and biopharmaceutical industry in Taiwan got a later start than advanced countries worldwide, most of which are small and medium enterprises. Sheng (2009), Yang, Sheng, and Huang (2010), Sheng, Liu, and Yang (2012) and Chen, Sheng, and Yang (2015) claimed biotech and biopharmaceutical corporations in Taiwan possess high proportion of research and development, long period of research and development, barriers to entry of high-tech industries and high-priced expense on research and development. Meanwhile, biotech and biopharmaceutical corporations require to value the channel and marketing and to emphasize the management of patent right and intellectual property right as well, implying the integral competitive environment without excessive funds and resources to lavish. Most of biotech and biopharmaceutical corporations in Taiwan also encounter the technique development, resources distribution, efficiency enhancement and reward on investment. As a result, how to precisely evaluate the performance with scientificization and datumization is becoming a new issue (Chiu, Hu, \& Tsao, 2003; Hsieh, Wann, \& Lu, 2007; Sheng, 2009; Yang et al., 2010; Sheng et al., 2012; Chen, Sheng, \& Yang, 2014; Chen et al., 2015).

The methods of evaluating performance researchers frequented to adopt in the past, including balanced score card (BSC), data envelopment analysis (DEA), stochastic frontier analysis (SFA), analytic hierarchy process (AHP), financial ratio analysis (FRA) and multivariate statistical analysis. The researchers concentrated on DEA of nonparametric methods and SFA of parametric methods for the relative research of biotech and biopharmaceutical corporations in Taiwan in the past. The research issues focused on the empirical analysis of cost efficiency, technical efficiency, financial performance, R\&D performance of manufactures. Of all the studies, Chen, Hu, and Ding (2005), Chiu, Chen, and Tsao (2005), Hsieh et al. (2007), Liang, Jiang, and Lai (2008), Yang et al. (2010) and Sheng et al. (2012) are the most noticeable, these literature reviews of which adopted DEA as the research approach, as well as Chiu et al. (2003), Yeh, Chen, and Chen (2007), Li and Li (2008), Sheng (2009), $\mathrm{Li}, \mathrm{Wu}$, and $\mathrm{Li}$ (2011) and Chen et al. (2014) adopted SFA. The literature reviews mentioned above without consistent conclusion. In other words, the researchers adopted different research methods or different performance evaluation might cause diverse empirical results and conclusions. The coverage of biotech and biopharmaceutical industry is so wide that the difference between individual manufactures might result in various possibilities of errors of performance evaluation as well. Accordingly, the researchers require taking these influential factors as regard to seek solutions in order to evaluate the performance precisely in biotech and biopharmaceutical industry in Taiwan. Besides, the relevant studies of performance for biotech and biopharmaceutical industry over-relied on DEA and SFA as methodology in the past, so Wu, Chang, and Lin (2008) and Sheng (2009) proclaimed these traditional methods of performance evaluation which were unable to appear the integral aspect of enterprise operation completely is the biggest limitation. The main reason is the operation variable of enterprise lessened evaluated by these methods. In the view of this, this study attempts to break traditional research limitations, proposing an innovative thinking and approach to precisely evaluate the 
performance for biotech and biopharmaceutical corporations completely in Taiwan.

The purpose of this study set up the evaluation mode of performance for biotech and biopharmaceutical corporations in Taiwan, which differentiated from the former studies. Modified Delphi approach was adopted to cope with collection of expert's questionnaire and evaluation criteria arranged by researchers while evaluating enterprise performance on this study. Furthermore, interpretive structural model (ISM) was adopted to analyze the association between these evaluation criteria and build up structure model. Then, fuzzy analytic network process (FANP) was analyzed to obtain the weight and criteria and sub-criteria. Finally, take top 10 biotech and biopharmaceutical corporations with market value as the research examples, in light of performance evaluation table as the result designed by FANP to evaluate the performance of manufactures. The research which process and empirical result are able to supply the insufficient former relevant literature reviews is an important reference for future study. On this study, the first chapter is the introduction, accounting for the development background, research motivation, purpose and research frame. The second chapter is literature review aiming at the elements of performance evaluation as financial performance, products and technology of R\&D, production and quality management, organization characteristics and operation management discussed individually. Methodology is as the third chapter, clarifying the methods adopted as modified Delphi approach, ISM, FANP and performance evaluation table. Chapter four is empirical result and analysis. The fifth chapter is conclusion.

\section{Literature Review}

The former relevant research results regarding performance have been extensively drawn on respective industry. Venkatraman and Ramanujam (1986), Kaplan and Norton (1996) and Van der Stede, Chow, and Lin (2006) emphasized the performance evaluation indicator of organization is able to connect with strategy. With regard of research issues of biotech and biopharmaceutical industry performance were showed in the literatures. The relevant literatures will be reviewed initially so as to build the performance evaluation indicator and evaluation mode effectively. Regarding comprehensive issues of performance evaluation researches, corporation evaluation will be affected by four factors: financial performance, product and R\&D technology, production and quality management and organization characteristics and operation management on this study.

\subsection{Financial Performance}

One of the purposes for enterprise operation and production is to make fortune, earn profits and enhance market value of enterprise. The researchers are merely unable to count on traditional financial indicator to evaluate the performance for these corporations due to the specific attribute of biotech and biopharmaceutical industry. Nevertheless, financial performance is still a key indicator performance to evaluate the enterprise operation. The former related literatures attempted to probe into enterprise financial performance with different angles and issues. Most of the financial performances are related to the financial operation, investments, stock price and profits in the enterprise. Eliasson (1976) assumed the enterprise started to plan integral operational policies from revenue in general. The growth of revenue is able to provide useful and distinct benchmark to encourage employees to attain the goals. Kaplan and Norton (1996) declared the financial statement is the key performance indicator in the enterprise. According to Aaker (1998), sustainable competitive advantage (SCA) possesses significant effect on enterprise performance. Sustainable competitive advantage incorporates the economy of scale, low-cost manpower or manufacturing automation to reduce the cost, which enables the enterprise to retain the advantage of low-cost in finance.

Ramezani, Soenen, and Jung (2002) stated the enterprise operation performance would be influenced by operating growth rate on the ground that the corporation revenue was from operating revenue. Operating revenue growth is not only the embodiment, but the operating growth is able to draw on the funds effectively, profitable revenue and profitable revenue growth, defined by Charan (2004). Enterprise operation performance incurred the restrains of limited determined price, market scale, and global competition frequently. Provided that the enterprise slashed the cost and enhanced the production, then the performance provided would not be able to meet the stockholders and employees' requirements. Consequently, sustainable operation growth enables to boost common development between the employees and enterprise. According to Kaplan and Norton (1992), Kaplan and Norton (1993) and Kaplan and Norton (2008), the scope of influencing operating revenue growth is wide, for example, the operation strategy, marketing strategy, human resources management factors and production process of high quality. The enterprise must take a variety of measures effectively to reach the financial goals, and then attain the enterprise performance.

Take the stock price and relationship of financial operation as the research topic, the stock price of corporation rose with the level of financial leverage discovered by Masulis (1983). Simultaneously, the value of corporation is related to the debt level positively. Jensen (1986) defined the free cash flow as the cash flow left by the 
enterprise investing all net present value in the plan is greater than zero; in addition, he mentioned the managers and stockholders held different attitude from distribution of free cash flow due to the differences of profits. Accordingly, agency costs occurred to influence the corporation performance. Jensen (1986) and Jensen (1989) declared the future performance of corporation would respond to the quality of current decision and strategy.

Further, the agent conflict between the managers and stockholders is the factor lasting effect on enterprise performance announced by Joseph and Richardson (2002). The managers and stockholders have different suggestions of sharing methods to residual cash of enterprise, which is the main reason. Additionally, Roberts and Mizouchi (1989) stated biotech industry required investing large-scale resources to develop aiming at the biotech industry with exclusive characteristics. The larger the investing amount in biotech and pharmaceutical corporations, the longer the capitol payoff period is. Hence, these corporations require more potent competence of financing retaining financial status in the long run.

\subsection{Products and $R \& D$ Technology}

Numerous high-tech corporations, including biotech and biopharmaceuticals require relying on constant innovative R\&D technology and products to maintain corporation advantage. A great deal former research literatures consent on the product and technology research and development as the measurement of key performance indicator for enterprise operation. The intangible assets possess some level of contribution with the creation of enterprise value (Osborne, 1998); besides, the patent is the storage of knowledge for enterprise organization as well as influences the performance remarkably, stated by DeCarolis and Deeds (1999). Bontis, Keow, and Richardson (2000), Tseng and Goo (2005), and Kijek (2012) proclaimed the same level of intellectual capital enabled to effect corporation performance, the reason of which was the intellectual capital to reflected the organization creation and to draw on the competence of new knowledge.

The investments in $R \& D$ in the enterprise facilitated the revenue growth indicated by partial studies. Griliches (1980) discovered the positive association between the competence of R\&D and production in the enterprise while focusing on trace the data of $R \& D$ in the manufactures from 1958 to 1963. In addition, Griliches (1981) observed the significant association among the evaluation of financial market, $R \& D$ investments and patent. Consequently, the R\&D investments and patent right is the core indicator to evaluate the operation performance. The R\&D would be able to affect the growth of future revenue in the manufacture revealed by Morbey and Reithner (1990), which is similar with the studies of Morbey and Reithner (1990). The study learned the marked and positive effects on profits between new product and the expenses on R\&D by Sougiannis (1994). Morbey and Dugal (1992) studied the less the corporation spent, the higher opportunities the revenue reduced during the course of economic recession. Megna and Klock (1993) and Hall (1993) took high-tech semi-conductor industry as the research object and learned the dedications to R\&D resources possessed the positive influence on the rate of return on investment case. The productivity would increase as well while increasing investments in the R\&D. Lasting accumulated R\&D investments enabled the corporation rewards retain more stable. The study of Lev and Sougiannis (1996) and Lev and Sougiannis (1999) indicated the enterprise earned 2.328 times operating profit margin as increasing R\&D expenses per unit.

Some studies stressed the dedication to R\&D resources and association between stock price and market value. The expenses on new products and R\&D technology possessed marked effects discovered by Sougiannis (1994). According to Lev and Sougiannis (1996) and Lev and Sougiannis (1999), the expenses on R\&D aimed at the performance of stock price in the enterprise on stock market. What is more, the expenses on technology development with future revenue possessed positive effects, as an intangible asset, the result of which enabled to account for the difference of market value in high-tech industry from accounting and book value. Further, R\&D capital, a risk, a traditional risk indicator is unable to manifest observed by Lev and Sougiannis (1996) and Lev and Sougiannis (1999). Jaffe, Trajtenberg, and Fogarty (2000) and Bosworth and Rogers (2001) showed the patent right was capable of enhancing operation performance related to the corporation value. Deeds (2001) explored the relevant effects on average proportion of expense on $R \& D$ in high-tech corporation, the competence of technology development and the numbers of corporations taking part in the research groups to value added of corporation market. As the result, these factors to market value added possessed positive effects. Pearl (2001) studied the financial date in 3500 corporations in the US from 1964 to 1988. The result of this study discovered the ratio between average market value and book value of corporation would increase $4.3 \%$ assuming the $\mathrm{R} \& \mathrm{D}$ expense went up to $1 \%$.

A few studies focused on exploring the effect on the enterprise finance and operation performance for the dedication of $\mathrm{R} \& \mathrm{D}$ resources in biotech industry from different countries. The applied frequency of patent right is related to operation performance in biotech corporation as empirical result observed by Pazderka (1999). 
Cumming and Macintosh (2000) regarded biotech industry in Canada as the research object, discovering the expenses is not quite similar with different R\&D stages in the enterprise. Generally speaking, it would cost greater outlay on early stage of R\&D. Relatively, the R\&D outlay cost less subsequent to the products or R\&D technology getting stable in biotech corporations. Meanwhile, Hall and Bagchi-Sen (2002) observed the effects on expenses on R\&D intensity and innovation measures to operation performance, taking biotech industry in Canada as the research object. Manufacture performance incorporated the general revenue, product sales revenue, royalty, and the revenue of inspection and experiment service among others. The study of Hall and Bagchi-Sen (2002) indicated there was not marked association between the innovative measures and general revenue in the manufactures. The empirical result showed the positive correlation between R\&D investments and enterprise financial performance. Besides, different R\&D investing strategies possessed differences as well. The biotech enterprise with higher R\&D technology values product research department rather than the enterprise with lower R\&D technology values sales department. Most of the literature reviews mentioned above reached a consensus on product and R\&D technology as the key indicator of measuring enterprise operation performance.

\subsection{Production and Quality Management}

Either in Taiwan or in other countries, most of biotech and biopharmaceutical corporations are part of manufacturing industry or the laboratory with well-equipped production and operation management system. As far as the manufacturing industry is concerned, well-equipped production, operation management and quality management become the resource of enterprise competition. The competition of enterprise incorporates service and quality, rate of return on investment and productivity generalized by Skinner (1969). Hence, imaginably and obviously, the performance of corporations enables to be measured by the factors of production, operation management and quality management. Fiegenbaum and Thomas (1990) deemed the control competence of providing products and limitation period of service would be able to be the foundation of obtaining competitive advantages. Consequently, production effectiveness is regarded as a resource for the enterprise. No matter push or pull production systems possessed their pros and cons; however, advanced production management systems brought about the huge profits for the enterprise exactly learned by Spearm and Zazanis (1992). According to Jesssop and Sum (2000), the enterprise increasingly stressed on the time management, production and operation management to enhance the performance during the course of globalization. Moreover, Jesssop and Sum (2000) indicated the advantage of rapid respond might not unable to be sensed by the managers or clients, yet the huge value would be eventually brought for the enterprise. Based on the just in time production as research issue, Fullerton and McWatters (2002) categorized the level of features of enterprise accordance and just in time production as well as explored the relationship between JIT and enterprise performance indicator. Corry and Kozan (2004) and Geraghty and Heavey (2005) stated the differences between production strategies adopted by the enterprise and production management system would influence corporation performance.

Quality management has been regarded as one of the most significant issues in the field of production and operation management in numerous literatures for the past years. Quality management is described as concrete accomplishments at the end of production and operation procedure; in the meantime, a key indicator to measure enterprise performance. White and Ruch (1990) emphasized the significance of quality management as well as regarded the quality as the first prior task in the enterprise. The enterprise devoted the enhancement of product quality so as to lessen unnecessary waste and to reduce production cost to ameliorate the efficiency. The study of Ittner and Larcker (1995) learned the association between total quality management (TQM) and the implementation of TQM and performance. The result discovered quality management affected on enterprise performance with some deferred characteristics. In other words, the efforts of enhancing service and product quality the enterprise put positively influenced on operation performance. Chenhall (1997) raised the key indicator related to TQM and discovered the effects of TQM on competence of enterprise revenue and operation performance. Otherwise, there were scholars mentioned valuing cost control and the significance of cost efficiency for creating outstanding operation performance by the enterprise. Kim and Mauborgne (2005) analyzed the cost control and the cost efficiency in value chain with noticeable influence on creating value for enterprise.

\subsection{Organization Characteristics and Operating Management}

The effective factors as the organization characteristics of enterprise include the enterprise scale, enterprise history, market share, brand image and human resources. The enterprise integral operating strategy, business mode and marketing strategy are involved in the enterprise operating management. Obviously, the organization characteristics of enterprise and operating management affected the operating performance and competition either directly or indirectly. The organization characteristics of enterprise and the situation of operating management resulted in the difference due to in the environment with various industries. This point of view has 
been proved by the numerous of former research literatures. Schumpeter (1950) analyzed the relationship the competition and integral industry structure in the similar industry, the result of which discovered the manufactures possessed noticeable effects on market monopoly for the enterprise scale, date of establishment and market share. Amato and Wilder (1990) indicated the corporation scale influenced operation performance.

Human resources management of enterprise affected the operating performance possibly. Becker (1964) and Williamson (1979) studied the relationship between events of human resources management and performance in the enterprise. The system of well-planned human resources management enabled the employees to own sense of participation, to dignify themselves and to reinforce the organizational commitment and loyalty for the enterprise. The advantages not only reduced the turnover rate, but also enabled the employees to work hard to enhance the performance. The study of Wright, Ferris, Hiller, and Kroll (1995) and Delaney(1996) observe the competences of appealing and retaining the elite would enable to maintain the competitive advantages persistently. The policies of human resource management and the attraction of enterprise prestige for employees possessed noticeable effects. Furthermore, the effects would influence the integral operating performance. Kaplan and Norton (1996) indicated the senior executives were able to convert their visions into the goals and strategies of middle executives firstly, and then into the mobile proposals and goals of first level personnel. The human resources in enterprise are able to associate with organizational performance indicator each other.

What is more, other factors as organization characteristics and operation management would be possibly able to influence operation performance for enterprise. Chenhall and Langfield-Smith (1998) stressed the management technology and the linked strategy of establishment enabled to promote organization performance. With well-image, social recognition and high-prestige, the operation performance would be better indicated by Benjamin and Podolny (1999). These products possessed higher competition to defeat the opponents more easily on the market, which enabled to increase the enterprise revenue and market share as well as to raise the operation performance. Based on the study of Roberts and Dowling (2002), the enterprise with market prestige, a key factor, to predict its rate of return on common stockholders' equity. The prestige of enterprise possessed positive effect on the rate of return on common stockholders' equity, that is to say. Turban and Cable (2003) studied the effects on enterprise prestige for enterprise attraction. With well prestige, the enterprise obtained higher competitive advantages on not only talented personnel market, but also on the market of product marketing. The higher client loyalty and the acquisition of resources were in favor of high-standard operation performance for enterprise. Saxton and Dollinger (2004) took the enterprise merger as the research topic to analyze the association between enterprise prestige and acquirer for enterprise evaluation. Obviously, the enterprise prestige would affect enterprise operation performance and merger determination of acquirer discovered by the research result. According to Lai, Chiu, Yang, and Pai (2010), the enterprise prestige, social image and enterprise brand associated with enterprise operation performance positively. The social image and prestige of enterprise assisted the asset in enhancing value of enterprise brand. Above all, the research needs to take various respects of organization characteristics and operation management into consideration comprehensively while evaluating the enterprise performance.

\section{Methodology}

Literature review and modified Delphi approach were adopted to construct the hierarchical framework on this study. To analyze and establish influential relationship between the elements, ISM was applied. Following by the establishment of hierarchy architecture, FANP was used to calculate overall weights and priorities of the elements. Subsequently, performance evaluation table was designed to help the organization figure out the optimal solution.

\subsection{Modified Delphi Approach}

Murry and Hammons (1995) amended traditional Delphi approach and announced modified Delphi approach. In accordance with Hill and Fowles (1975) and Stewart (1987), traditional Delphi approach could be regarded as a group communication and process of co-decision. In the process of proceeding with the questionnaire analysis mainly, every member was allowed to express his/her opinion on certain issue with equal value. The researcher stood out the replied opinions and sought the consensus through comprehensive experts, scholars, the expertise and opinions of profitable groups. Without insufficient strict qualitative research, Delphi approach, the scientificity and systematicness of quantitative research was thoroughly applied. The researcher could apply Delphi approach to search the consensus of the experts with high-ambiguity, high-complexity and argumentative issues. Consequently, Delphi approach possessed some advantages as brainstorming, retaining dependent discrimination of experts, breaking temporal isolation dilemma and unnecessary complex statistics. Rowe and Wright (1999) stated traditional Delphi approach was supposed to be the participation with anonymous groups. 
For this reason, the advantage of collective decisions of experts and brainstorming could be retained, on the other hand, the possible interruption for issue discussing avoid by experts while communicating face to face. Besides, selecting appropriate numbers of experts, scholars or practitioner of traditional Delphi approach is the primary measure. The expert panel with ten people above enabled to obtain the minimum deviation from statistics, but the maximum reliability of groups proclaimed by Dalkey (1969). The numbers of members are supposed to be 15 to 30 members with high homogeneity of expert panel members suggested by Delbecq, Van de Ven, and Gustafson (1975). The numbers of members are supposed to be from 5 to 10 members assuming the expert panel is the group with high heterogeneity.

However, the analytic process of tradition Delphi approach is not without any defects or controversy. Hill and Fowles (1975) stated these so-called 'experts' whether enabled the research topic to possess proficiency in the process of selecting members of expert group. Moreover, the process of awareness of issues, problem analysis and consensus formation was overly lengthy in the traditional Delphi approach, which has resulted in the deviation of principle at all times. Murry and Hammons (1995) presented modified Delphi approach and attempted to figure out the defect. The specific implementation and statistical mode of modified Delphi approach is similar to traditional Delphi approach, but the difference is Murry and Hammons (1995) ignored the complex steps on open-end questionnaire in the first round. The structured questionnaire was directly developed by the research results in literature reviews or the researcher's plan, as well as the ways of expert interviews. Modified Delphi approach is able to economize the time and the assumptions of open-end questionnaire, which enables the expert group to pay attention on research topic and raise the response rate of questionnaire as taking part in the research.

\subsection{Interpretive Structural Model}

ISM was stated by Warfield (1973a), Warfield (1973b), Warfield (1974), Warfield (1975), Warfield (1976), and Warfield (1990) to analyze and structure the approach of complex associated mode between the elements in one system. In a meantime, Warfield (1973a) presented three suggestions for the ways of drawing up the strategy and structuring model. Primarily, the researcher is supposed to improve the basic concept of building analytic model. Then, the researcher adapts the mathematical linguistics to build the model. Finally, the researcher is supposed to convey the crucial ideal and simple improved projects through built analytic model. Hence, ISM has been described as an innovative approach with the elements of effective analytic system, as well as a useful technology with quantitative aid (Senecal, Kalczynski, \& Nantel, 2005). ISM, a quantitative approach, applied the relationship among different types of elements to reform into relation hierarchy graph accounted for by Warfield (1974). ISM is adapted to elaborate the relationship among different types of elements by the means of the concepts of hierarchical digraph and discrete mathematics in graphic theory drawn on the analysis. The researcher takes advantage of ISM to present the association among all the elements in one system combining with the behavioral science, the mathematics concept, the group decision and the computer-aid. Finally, the hierarchy with more complete multi-level structure is called 'map'. As a result, the decision maker would be able to organize the information and concept definitely and systematically, as well as to improve the integral awareness. In other words, the aim of developing ISM is to collect and compact the information to analyze the model structurally. Then, the researcher is able to establish the tool of management decision so as to figure out and analyze the troubles in the complex situation.

Traditionally, attempting to discover the relation among different elements, the numerous of research approaches depend on the opinions and senses from the researchers or testees. Tazki and Amagsa (1997) stated people rely on their intuition and experience discriminating and considering complex and diverse issues in the process of researching at all times. The researcher must take a number of impact factors and combination to be the formation of hierarchy while proceeding with the complex issues or the researches of managing the organization or the systematic tasks. Nonetheless, the more impact factors or the more complex associated level, the harder the discovery of existent association directly. Through ISM, the associated sequence among all elements in the complex system could be analyzed by the researcher, as well as built the structure with hierarchical association by quantitative approach. ISM is not only adapted to figure out the variety of levels with abstract issues, but also used to develop the deeper issues and conceptual understanding. Moreover, the manager would establish more effective decisions by further design and projecting the detailed solutions. According to the research of Tazki and Amagsa (1997), Jharkharia and Shankar (2004) and Ravi, Shankar and Tiwari (2005), ISM enabled the researcher to ponder over the complex issues systematically and logically. Based on the relation among all variables by defining a problem or an issue, the researcher is able to construct integral systemic structure.

ISM, mainly spilt into a couple of steps as below, is through the process of binary matrices: 
Step 1. Direct association among components of analytic system: Assume the set $S$ is formed by nth factors, then $S=\left\{S_{1}, S_{2}, \ldots, S_{n}\right\} .\left(S_{i}, S_{j}\right)$ is the ordered pair between $S_{i}$ and $S_{j}$. All factors in set $S$ must be binary relation one another. The research result would combine with this step by modified Delphi approach.

Step 2. Adjacency matrix: Adjacent matrix is also called relation matrix, the aim of which is to discover the mutual relation among the factors. The relative facto discovered from the system is defined as $C_{i}, i=$ $\{1,2,3, \ldots, n\}$. Place the factor into the matrix and proceed with pairwise comparison. Assume the factor $C_{i}$ in the row is directly related to the factor $C_{j}$ in the column, then $A=\left[a_{i j}\right]$ existed defined as:

$$
\begin{aligned}
& a_{i j}= \begin{cases}1 & \text { suppose } i \text { influenced on } j \\
0 & \text { suppose } i \text { had no influence on } j\end{cases} \\
& A=\begin{array}{c}
C_{1} \\
C_{2} \\
\vdots \\
C_{n}
\end{array}\left[\begin{array}{cccc}
C_{1} & C_{2} & \cdots & C_{n} \\
0 & a_{12} & \cdots & a_{1 n} \\
a_{21} & 0 & \cdots & a_{2 n} \\
\vdots & \vdots & \ddots & \vdots \\
a_{n 1} & a_{n 2} & \cdots & 0
\end{array}\right]
\end{aligned}
$$

Step 3. Reachability matrix: Add adjacency matrix $A$ with identity matrix $I$ to form matrix $M$. Then, use Boolean algebra to proceed with continued product for matrix $M$. Reachability matrix $M *$ is acquired as matrix $M$ reaches convergence.

$$
M^{h}=M^{h+1}=M^{*} \quad h>1
$$

Step 4. Hierarchy graph: Apply reachability matrix $M^{*}$ to convert into hierarchy matrix. According to reachability matrix $M^{*}$, reachability set $R$ and priority set $P$ are able to be calculated.

$$
\begin{gathered}
R=\left\{C_{i} \mid m_{j i}^{*}=1\right\} \\
P=\left\{C_{i} \mid m_{i j}^{*}=1\right\} \\
R \cap P=R
\end{gathered}
$$

Finally, the related structure graph is able to be constructed by means of the association between the core factors and other factors.

\subsection{Fuzzy Analytic Network Process}

AHP was proposed by Thomas L. Saaty in 1971. It is one of the well-known multiple criteria decision making (MCDM) techniques. AHP is adopted to systemize and stratify the complicated questions to deduct the risk of fault decision. Van Laarhoven and Pedrycz (1983), using the concept of fuzzy to solve the values in the pairwise comparison matrix with subjectivity, imprecision and vagueness...etc in traditional AHP, who stated fuzzy analytic hierarchy process (FAHP). Saaty (1996) introduced analytic network process (ANP) to deal with the problem of dependence and feedback existed between the elements. This research applied FANP to calculate overall weights of the elements.

Computational procedure of FANP:

Step 1: Constructing the hierarchical framework

Literature review and modified Delphi approach was adopted to construct the hierarchical framework on this study. To analyze and establish influential relationship between the elements, ISM was applied. Following by the establishment of hierarchy architecture, each evaluator respectively enables to give pairwise comparison matrices by a nine-point scale.

Step 2: Constructing fuzzy pairwise comparison matrices

Buckley (1985) reported the adoption of geometric mean to integrate the opinions of experts enables to enhance consistency and precision of factor judgment. The score of geometric mean from all survey respondents is made up as the middle value $\left(M_{i j}\right)$ of triangular fuzzy number (TFN) on this study. The largest value and the smallest value of score among all survey respondents are made up respectively as the upper bound $\left(U_{i j}\right)$ and lower bound $\left(L_{i j}\right)$ of TFN. For example, the pairwise comparison values from 5 experts are as $8,0.33,5,4,0.5$, the fuzzy number of which is $(0.33,1.92,8.00)$. Subsequent to the combined opinions from all experts, the fuzzy positive reciprocal matrix is built immediately. 


$$
\tilde{T}=\left[\begin{array}{cccc}
1 & \widetilde{t_{12}} & \cdots & \widetilde{t_{1 n}} \\
1 / \widetilde{t_{12}} & 1 & \cdots & \widetilde{t_{2 n}} \\
\vdots & \vdots & \vdots & \vdots \\
1 / \widetilde{t_{1 n}} & 1 / \widetilde{t_{2 n}} & \cdots & 1
\end{array}\right]
$$

where $\tilde{\mathrm{t}_{\mathrm{j}}}=\left(\mathrm{L}_{\mathrm{ij}}, \mathrm{M}_{\mathrm{ij}}, \mathrm{U}_{\mathrm{ij}}\right)$

\section{Step 3: Defuzzification}

Liou and Wang (1992) was adopted to transform fuzzy number into crisp value on this study. The method is expressed in equation (8). $\alpha$ denotes the risk preference of decision makers. The value of $\alpha$ is set between 0 and 1 . The larger the number, the more stable the decision making environment. $\beta$ denotes the risk tolerance of decision makers. The value of $\beta$ is set between 0 and 1 . The larger the number, the higher the risk.

$$
\begin{gathered}
D_{\alpha, \beta}\left(\widetilde{t_{l j}}\right)=\left[\beta \cdot f_{\alpha}\left(L_{i j}\right)+(1-\beta) \cdot f_{\alpha}\left(U_{i j}\right)\right] \\
\text { where } f_{\alpha}\left(L_{i j}\right)=\alpha\left(M_{i j}-L_{i j}\right)+L_{i j} \\
f_{\alpha}\left(U_{i j}\right)=U_{i j}-\alpha\left(U_{i j}-M_{i j}\right)
\end{gathered}
$$

$\alpha \in[0,1] \quad \beta \in[0,1]$

Equation (9) represents the single pairwise comparison matrix.

$$
D_{\alpha, \beta}(\tilde{T})=\left[\begin{array}{cccc}
1 & D_{\alpha, \beta}\left(\widetilde{t_{12}}\right) & \cdots & D_{\alpha, \beta}\left(\widetilde{t_{1 n}}\right) \\
1 / D_{\alpha, \beta}\left(\widetilde{t_{12}}\right) & 1 & \cdots & D_{\alpha, \beta}\left(\widetilde{t_{2 n}}\right) \\
\vdots & \vdots & \vdots & \vdots \\
1 / D_{\alpha, \beta}\left(\widetilde{t_{1 n}}\right) & 1 / D_{\alpha, \beta}\left(\widetilde{t_{2 n}}\right) & \cdots & 1
\end{array}\right]
$$

Step 4: Calculating eigenvectors and analyzing consistency $\lambda_{\max }$ and $X$ denote the eigenvalue and eigenvector of the single pairwise comparison matrix $D_{\alpha, \beta}(\widetilde{T})$ respectively.

$$
\mathrm{D}_{\alpha, \beta}(\widetilde{\mathrm{T}}) \cdot \mathrm{X}=\lambda_{\max } \cdot \mathrm{X}
$$

To ensure the logic judgment of expert fulfills the consistency, consistency ratio $(C R)$ is used to measure (Saaty, 1980). The level of consistency of matrix is satisfying if the value of $C R$ is less than 0.1 .

$$
C R=C I / R I
$$

where consistency index $(C I)=\left(\lambda_{\max }-\mathrm{n}\right) /(\mathrm{n}-1)$

random index $(R I)$ is the average index for randomly generated weights

Step 5: Constructing supermatrix

All eigenvectors are gathered together to become a supermatrix. A standard form of a supermatrix is shown as equation (12) (Saaty, 1996). $\mathrm{W}_{21}$ indicates the influence of the goal on the criteria. $\mathrm{W}_{22}$ represents the internal dependence of the criteria. $\mathrm{W}_{32}$ denotes the influence of the criteria on the alternatives. $I$ and 0 represent the identity matrix and the zero matrix respectively. A supermatrix comprises all elements of the goal $(G)$, the criteria $(C)$ and the alternatives $(A)$.

$$
\mathrm{M}_{\text {super }}=\underset{\mathrm{C}}{\mathrm{C}}\left[\begin{array}{ccc}
G & C & A \\
0 & 0 & 0 \\
\mathrm{~W}_{21} & \mathrm{~W}_{22} & 0 \\
0 & \mathrm{~W}_{32} & \mathrm{I}
\end{array}\right]
$$

The matrix $M_{\text {super }}$ is the unweighted supermatrix which needs to be normalized to satisfy the column-stochastic principle. In other words, using the method of normalization to make each column of the matrix sum to one. Such kind of stochastic matrix is called weighted supermatrix. In order to achieve convergence status, the weighted supermatrix to the power of $2 k+1$ is processed. The number of $k$ is subjectively determined. The multiplication stops until the columns of the supermatrix become identical. After the calculation of limiting described above, a weighted supermatrix can be transformed into a limiting supermatrix. The overall 
priorities of the elements are obtained by normalizing the limiting supermatrix. On this study, only the elements of the goal and the criteria were listed in the supermatrix to calculate overall weights.

\subsection{Performance Evaluation Table}

The ideal of performance evaluation table on this study is based on the evaluation presented simply and rapidly by the decision maker while taking several alternatives into account. Fill in 'Alternative', 'Evaluator' and 'Date' to analyze the result through FANP and list the name and weight of all criteria and sub-criteria as below. Table 2 is accounted for the evaluation explanation of evaluation table established by decision maker, the sequence of which is rated respectively by seven ranks is: Extremely good (Scores 86-100), Quite good (Scores 71-85), Slightly good (Scores 56-70), Average (Scores 46-55), Slightly bad (Scores 31-45), Quite bad (Scores 16-30) and Extremely bad (Scores 0-15). The product multiplied by the score of all criteria from weight and real rating of all sub-criteria, as well as the sum is the total scores in all sub-criteria. The best decision presented according to the score of all criteria and the rank of total rank.

Table 2. Performance evaluation table

\begin{tabular}{lcll}
\hline Alternative: & & Evaluator: & Date: \\
\hline Criteria(Weight): & Sub-criteria(Weight): & Score: & Score Note: \\
A & A1 & & 86-100: Extremely good \\
& A2 & & 71-85: Quite good \\
& $\vdots$ & & 56-70: Slightly good \\
B & B1 & 46-55: Average \\
& B2 & 31-45: Slightly bad \\
& $\vdots$ & 16-30: Quite bad \\
C & C1 & $0-15:$ Extremely bad \\
& C2 & \\
Total Score: & $\vdots$ & & \\
\hline
\end{tabular}

\section{Empirical Results}

The study sequentially applied four types of research approaches in order to build the evaluation modes of operation performance in Taiwan biotech and pharmaceutical corporations, incorporating modified Delphi approach, ISM, FANP and performance evaluation table. In accordance with literature review and fifteen executives at high-level in Taiwan biotech and pharmaceutical corporations, subsequent to the questionnaire of expert interview through modified Delphi approach, proposed by Murry and Hammons (1995) as the first stage to compile 4 criteria and 18 sub-criteria considered while assessing the operation performance in the corporation, as Figure 2. These fifteen experts with more than 10-year work experience possess fair awareness and research in depth in the biotech and pharmaceutical industry. Dalkey (1969) and Delbecq et al. (1975) suggested the numbers of expert team with high homogeneity be more than 10 people. All experts were supposed to sift the significance and supply the suggestions aiming at all criteria and sub-criteria via several persistent feedbacks until they reached the consensus. The explanation of criteria and sub-criteria is shown as Table 3. 


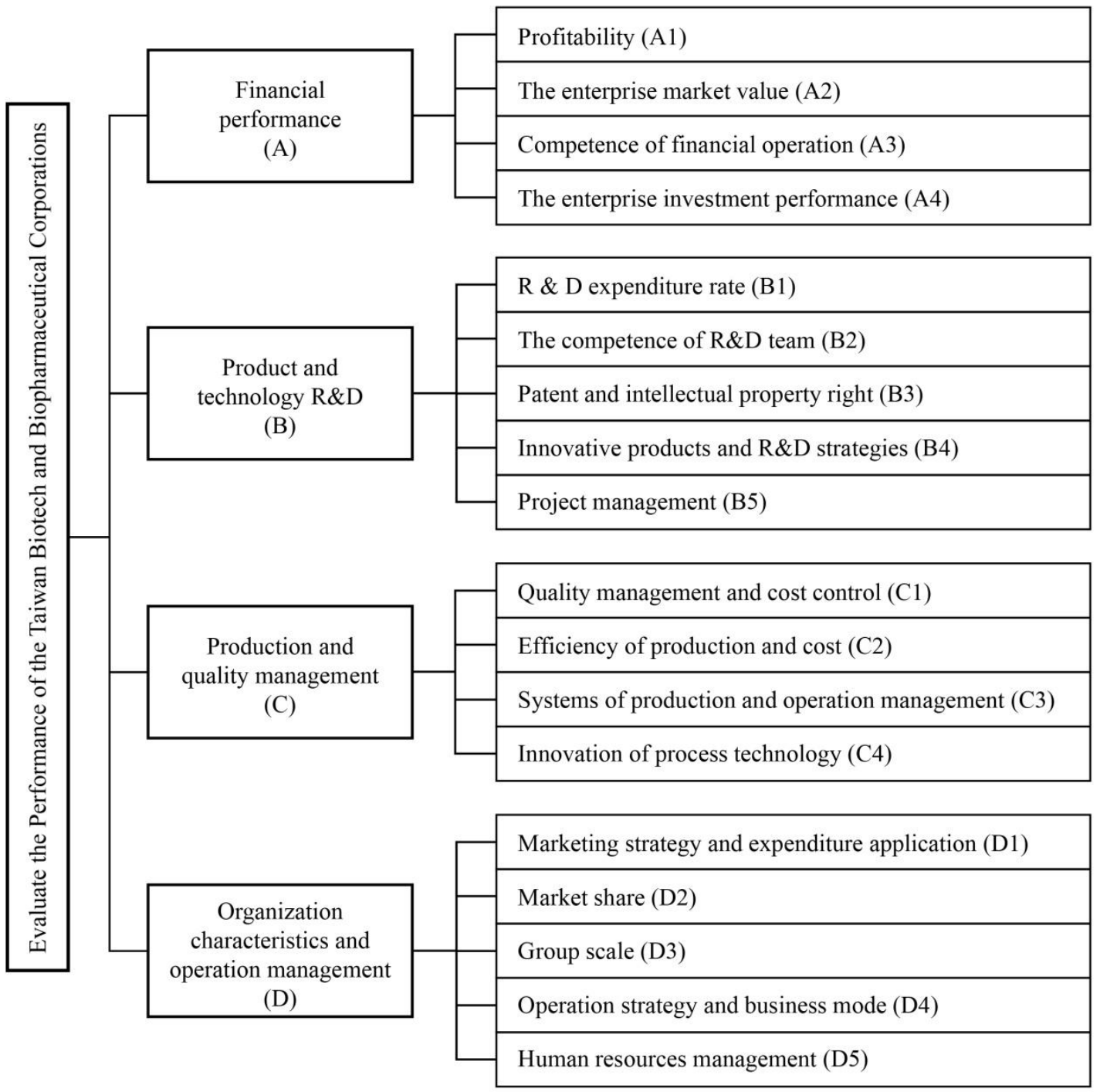

Figure 2. Hierarchical structure of problem in application

Table 3. Explanation of criteria and sub-criteria

\begin{tabular}{ll}
\hline Criteria and Sub-criteria & Explanation \\
\hline $\begin{array}{l}\text { Financial performance (A) } \\
\text { Profitability (A1) }\end{array}$ & $\begin{array}{l}\text { The enterprise profitability indicator showing the operation revenue and the amount of profit and standard } \\
\text { mainly as well incorporates operating profit ratio, ratio of profits to cost, cash earnings coverage ratio, return } \\
\text { on total assets ratio, rate of return on common stockholders' equity and rate of return on capital. } \\
\text { The enterprise market value refers to the market value on the stock market. On the premise of fixed capital } \\
\text { structure of enterprise, the higher the integral value, the greater the value of equity capital of enterprise. } \\
\text { (A2) }\end{array}$ \\
$\begin{array}{l}\text { Indeed, the stock value of enterprise is getting higher. Hence, the enterprise stock price accomplishing the } \\
\text { value market is determined by enterprise value. }\end{array}$ \\
$\begin{array}{l}\text { Financial operation is attributed to take advantage of various financial management technology, capital } \\
\text { allocation and financial leverage in order to require the profit, cost reduction and working capital. The } \\
\text { operation (A3) }\end{array}$ \\
$\begin{array}{l}\text { enterprise with advanced competence of financial operation possesses more opportunities to figure out the } \\
\text { financial problems by more effective solution than the same business. For example, the biotech and } \\
\text { biopharmaceutical corporations need more financial operation competence to go through lengthy period of } \\
\text { product R\&D. } \\
\text { The enterprise investment refers to invest in single or several investing cases by fortune and resources to } \\
\text { anticipate earning the revenue in the future. Frequently, the larger the amount the high-tech industry invested } \\
\text { in, the longer the capital payoff period is. Accordingly, the enterprise investment performance in high-tech }\end{array}$
\end{tabular}


Criteria and Sub-criteria Explanation

corporations depends on the financing competence and lasting stable financial support.

Product and technology R\&D (B)

R\&D expenditure rate (B1) R\&D expenditure rate is prescribed as the expenditure consumed on R\&D invested by the enterprise, accounting for its proportion within the turnover. The enterprise retains its competitive advantages by means of development of new products and upgrade of old products. As a result, the biopharmaceutical corporations enhance $R \& D$ rate to reinforce the development of enterprise effectively. In other words, R\&D expenditure rate demonstrated the current ambitious of enterprise and possible profits in the future.

The competence of $R \& D$ The researcher is as a basic unit to compose a R\&D department in the enterprise. The proportion of R\&D team (B2) personnel plunging is a decisive factor of influencing the competence of R\&D team. The rate of researchers refers to the quantity and quality of researchers, accounting for the proportion of the sum in human resources.

Patent and intellectual Patent and intellectual property right is described as the governmental department entitled inventors to invent property right (B3) exclusive rights by the means of producing, marketing or other ways within the time limit. Patent and intellectual property right is split into three types as invention, utility model and industrial design. The enterprise is able to preserve its own right effectively and privilege of forbidding other people to use while possessing the patent and intellectual property. Therefore, the patent and intellectual property belongs to one part of intangible property in enterprise as well as affects on either or future profits.

Innovative products and Technology R\&D refers to the reliable quality, feasible cost and innovative products are transferred by the R\&D strategies (B4) R\&D results of Science and Technology. The technology, products and services are enhanced substantially by the adaptation of innovative products and R\&D strategies. The development and R\&D associated with each other so closely that the development of new technology would result in the brand new product revolution.

Project management (B5) Project management is defined as the knowledge of management studies, implement and technology the manager draws on to figure out the problems as executing the project or fulfilling the demand of project. In the era of Knowledge-based economy, enhancing project management is a significant way to survive. How to possess potent project management is a key indicator of enterprise development as well.

Production and quality management (C)

Quality management and The products manufactured by the enterprise not only possess the functionalities as the reliability, the security cost control (C1) and the completeness. What is more, quality management and cost control must be organized and implemented by the enterprise. As a result, quality management and cost control facilitate the enterprise to improve its way of operation management and production, resulting in good prestige and potential profits for the enterprise. Cost and quality, more traditional competitive conditions though, command the most competition of products and services for the enterprise.

Efficiency of production Production efficiency referred to the ratio between the real output of process and maximum output under the and cost $(\mathrm{C} 2)$ fixed input; otherwise, it is able to reflect the level of maximum output, projected goal or the optimal operating service the enterprise reached. Cost efficiency indicated the difference between the input factor prices and output under the cost per unit. How the enterprise cuts down the cost, enhances the production efficiency and promotes the quality becoming the key indicator that whether the enterprise possesses competitive advantages while encountering the increasing intense competitive environment in global.

Systems of production and The enterprise takes advantage of the systems of production and operation management effectively to use the operation management production resource so as to fulfill the goals of operation and profits. The systems of production and operation (C3) management enable the enterprise to put the clients up to meet their needs in society, the products and services of market requirements. Accordingly, the systems of production and operation management not only efficiently manufacture the products or provide the services, but also bring about the lasting advantages for the enterprise.

Innovation of process The innovation of process technology is defined as the events that the enterprise adapted research and drew technology (C4) on innovative production technology, operating programs and approaches to enhance the product quality and production efficiency. The enterprise is able to economize the energy effective, mark down the consumption of raw materials and reduce the product cost by means of the innovation of process technology. Furthermore, the innovation of process technology enables the enterprise to defeat the competitor to stand out in the battle of orders from time to time.

Organization characteristics and operation management (D)

Marketing strategy and Take the customer's requirements as a starting point, the enterprise obtained the crucial data regarding the expenditure application customer's requirements and ability of purchasing in accordance with past experience. The enterprise enables (D1) to organize all operating events by means of using marketing strategies and marketing expenditure well. Broadly speaking, marketing strategy is a series of strategies as product strategy, price strategy, channel strategy and promotion strategy coordinated by the enterprise to achieve the marketing goal. 


\begin{tabular}{|c|c|}
\hline Criteria and Sub-criteria & Explanation \\
\hline Market share (D2) & $\begin{array}{l}\text { Market share refers to the ratio occupied by the product or service in the same kind competitive marketing } \\
\text { within a certain time. Under the circumstance of fixed market, the higher market share the corporation is, the } \\
\text { greater the product sales are. Hence, the market share not only shows the control of market and price, but also } \\
\text { discriminates the enterprise competition as the significant factor. }\end{array}$ \\
\hline Group scale (D3) & $\begin{array}{l}\text { The current enterprise operating modes are based on the group operation. Generally speaking, group scale } \\
\text { incorporates the scope of enterprise operation, the level of diversification, the organization of group and } \\
\text { revenue scale. The group scale with variety of types is formed by different gradations and the combination of } \\
\text { different production factors. In general, adequate group scale assists the enterprise to enhance its competition } \\
\text { and dominance on the market. }\end{array}$ \\
\hline $\begin{array}{l}\text { Operation strategy and } \\
\text { business mode (D4) }\end{array}$ & $\begin{array}{l}\text { The operation strategy and business mode are referred as the reaction the enterprise adapted to create the } \\
\text { survival and the developed space in fierce and competitive business environment while taking its own pro and } \\
\text { cons into consideration. Also, it revealed the role and the value in the enterprise plays in the supply chain and } \\
\text { the value chain. The superior and feasible operation strategies and business mode enable the enterprise to } \\
\text { possess the revenue and profits with stability and sustainability. }\end{array}$ \\
\hline $\begin{array}{l}\text { Human resources } \\
\text { management (D5) }\end{array}$ & $\begin{array}{l}\text { Human resources management refers to of a series of human resources policies and the related management } \\
\text { events. Human resources management includes a series of process as the employee recruitment, the training, } \\
\text { the appointment, the evaluation, the encouragement and the adjustment. The eventual goal of these events is } \\
\text { to facilitate the enterprise to fulfill the goal. The goal and strategy of human resources management with } \\
\text { coherence and perspicacity enable the enterprise to effectively use the resources, reduce the cost, enhance the } \\
\text { profitability and satisfy the market demands. }\end{array}$ \\
\hline
\end{tabular}

The mutual associated mode was used by the analysis of ISM and structure of sub-criteria at the second stage. As the result, the study on this research applied the result acquired at the first stage to design the questionnaire. Aiming at all sub-criteria proceeded with pairwise by inviting these same fifteen experts so that adjacency matrix of ISM analysis is appeared as Table 4. Following the adding adjacency matrix with identity matrix, the convergence is the continued product of matrix as the arithmetic, acquiring reachability matrix. The associated structure chart among the sub-criteria is shown as Figure 3.

Table 4. Adjacency matrix

\begin{tabular}{lllllllllllllllllll}
\hline & A1 & A2 & A3 & A4 & B1 & B2 & B3 & B4 & B5 & C1 & C2 & C3 & C4 & D1 & D2 & D3 & D4 & D5 \\
\hline A1 & 0 & 1 & 0 & 0 & 1 & 1 & 0 & 1 & 0 & 0 & 0 & 1 & 1 & 1 & 0 & 1 & 1 & 0 \\
A2 & 0 & 0 & 1 & 0 & 0 & 0 & 0 & 0 & 0 & 0 & 0 & 0 & 0 & 0 & 0 & 1 & 1 & 0 \\
A3 & 1 & 1 & 0 & 1 & 1 & 0 & 0 & 1 & 0 & 0 & 0 & 0 & 0 & 1 & 1 & 1 & 1 & 0 \\
A4 & 1 & 1 & 0 & 0 & 1 & 0 & 0 & 1 & 0 & 1 & 0 & 0 & 0 & 0 & 1 & 1 & 1 & 0 \\
B1 & 1 & 1 & 0 & 1 & 0 & 1 & 1 & 1 & 0 & 1 & 1 & 1 & 1 & 0 & 1 & 1 & 1 & 0 \\
B2 & 1 & 1 & 0 & 0 & 0 & 0 & 1 & 1 & 1 & 1 & 1 & 1 & 1 & 0 & 1 & 1 & 1 & 0 \\
B3 & 1 & 1 & 0 & 1 & 1 & 1 & 0 & 1 & 0 & 1 & 1 & 1 & 1 & 1 & 1 & 1 & 1 & 0 \\
B4 & 1 & 1 & 0 & 1 & 1 & 1 & 1 & 0 & 0 & 1 & 1 & 1 & 1 & 1 & 1 & 1 & 1 & 0 \\
B5 & 1 & 1 & 1 & 1 & 0 & 0 & 0 & 0 & 0 & 1 & 1 & 1 & 1 & 1 & 0 & 0 & 0 & 1 \\
C1 & 1 & 1 & 1 & 1 & 0 & 0 & 0 & 1 & 0 & 0 & 1 & 1 & 1 & 1 & 1 & 1 & 1 & 0 \\
C2 & 1 & 1 & 0 & 0 & 1 & 1 & 0 & 1 & 0 & 1 & 0 & 0 & 1 & 1 & 1 & 1 & 1 & 0 \\
C3 & 1 & 0 & 0 & 0 & 0 & 0 & 0 & 1 & 0 & 1 & 1 & 0 & 1 & 0 & 1 & 1 & 1 & 0 \\
C4 & 1 & 1 & 0 & 1 & 1 & 1 & 1 & 1 & 0 & 1 & 1 & 1 & 0 & 0 & 1 & 1 & 1 & 0 \\
D1 & 1 & 1 & 0 & 0 & 0 & 0 & 0 & 0 & 0 & 0 & 0 & 0 & 0 & 0 & 1 & 1 & 1 & 1 \\
D2 & 1 & 1 & 0 & 0 & 1 & 0 & 0 & 1 & 0 & 0 & 0 & 0 & 1 & 1 & 0 & 1 & 1 & 1 \\
D3 & 1 & 1 & 1 & 0 & 1 & 1 & 0 & 1 & 0 & 1 & 1 & 1 & 1 & 1 & 1 & 0 & 1 & 1 \\
D4 & 1 & 1 & 1 & 1 & 1 & 0 & 0 & 1 & 0 & 1 & 1 & 1 & 1 & 1 & 1 & 1 & 0 & 1 \\
D5 & 1 & 1 & 0 & 0 & 0 & 1 & 0 & 0 & 1 & 1 & 1 & 0 & 0 & 0 & 0 & 0 & 0 & 0 \\
\hline
\end{tabular}


(A) Financial performance (B) Product and technology R\&D

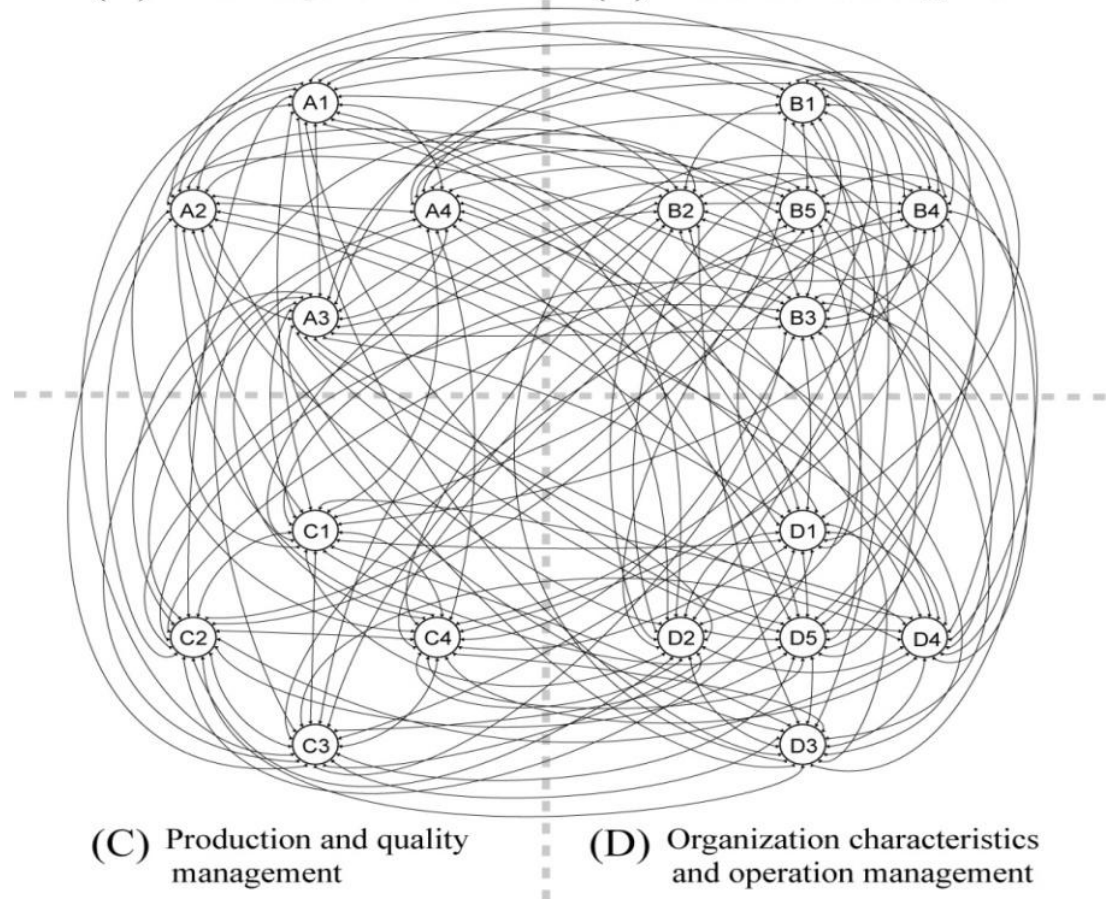

Figure 3. Structure chart among the sub-criteria

Subsequent to the building the relationship of hierarchical structure, the third stage is to fill out the expert questionnaire of FANP. These 15 experts interviewed previously proceeded with pairwise criteria, pairwise sub-criteria and pairwise comparison of dependability on this study. Then, the expert questionnaires were complied by advance integration to proceed with the analysis. The software of Matlab and Super Decision are used. The empirical result at this stage took the second layer as the example to explain progressively. According to the study method, fuzzy pairwise comparison matrix of each criterion in level 2 is complied as equation (13).

$$
\widetilde{T_{2}}=\left[\begin{array}{cccc}
(1,1,1) & (0.25,0.66,2.00) & (0.33,1.59,4.00) & (2.00,3.30,6.00) \\
(0.50,1.51,4.00) & (1,1,1) & (0.50,2.22,5.00) & (2.00,4.23,6.00) \\
(0.25,0.63,3.00) & (0.20,0.45,2.00) & (1,1,1) & (0.50,2.08,5.00) \\
(0.17,0.30,0.50) & (0.17,0.24,0.50) & (0.20,0.48,2.00) & (1,1,1)
\end{array}\right]
$$

Prior to the defuzzication, the risk preference of decision makers $\alpha$ and the risk tolerance of decision makers $\beta$ are required determining by the decision-maker. The environment of Taiwan biotech and pharmaceutical industry encountered some issues such as the less R\&D resources, the poor resource integration, the insufficient technological uniqueness, the difficulty of fund-raising, the deficient in economic scale, uncoordinated related constitution and insufficient talented personnel and so on, leading to the erratic entire decision-making environment. Furthermore, due to the lengthy of $R \& D$, delaying product development, high-cost of $R \& D$ and high failure rate, the industry, R\&D-centered, explored to high risk. The environment influenced tremendously the decision-making, thus value $\alpha$ set as 0.2 ; value $\beta$ set as 0.8 owing to the higher risk tolerance of decision-maker's. The aggregate pairwise comparison matrix for level 2 is shown as equation (14).

$$
D_{0.2,0.8}\left(\widetilde{T_{2}}\right)=\left[\begin{array}{llll}
1.0000 & 0.6122 & 1.1708 & 2.9004 \\
1.6335 & 1.0000 & 1.5642 & 3.0868 \\
0.8541 & 0.6393 & 1.0000 & 1.5352 \\
0.3448 & 0.3240 & 0.6514 & 1.0000
\end{array}\right]
$$

The eigenvector mutually compared among criteria and sub-criteria computed base on the formula. As the value of $C I$ is 0.0121 of criteria and the value of $R I$ is 0.90 of four comparability factors, the value of $C R$ is 0.0134 . The level of consistency of matrix is satisfying because the value of $C R$ is less than 0.1 . The value of $C I$ and the value of $C R$ of all pairwise comparison matrixes among sub-criteria passed consistent verification via assay. The analysis result of FANP is shown as Table 5. 
The significance of criteria is "Product and technology R\&D" (0.3841), "Financial performance" (0.2767), "Production and quality management" $(0.2195)$ and "Organization characteristics and operation management" (0.1197) in sequence. The result met the current situation in Taiwan biotech and pharmaceutical industry, which is similar with the research result of Yang et al. (2010), Sheng et al. (2012) and Chen et al. (2014) in the meanwhile. Possessing the superior product and advanced technology has influenced vitally on the operation performance in biotech and pharmaceutical corporations. The irreplaceable competitive advantages in the enterprise is transformed by the R\&D resources and of products and technology invested by the enterprise and specific results acquired by R\&D team. Likewise, the efforts the biotech and pharmaceutical corporations made maintain continually the composition, the rate of market share and conglomerate goodwill for the corporations. Consequently, different weight gap authentically reflected current situation and cognition of experts in the industry as a whole.

The top 5 key sub-criteria influence the evaluation of corporation operating performance in biotech and pharmaceutical corporations in Taiwan are "Profitability" (0.1274), "Efficiency of production and cost" $(0.1145)$, "Innovative products and R\&D strategies" (0.0941), "Quality management and cost control" (0.0837) and "Operation strategy and business mode" (0.0835). Comparatively speaking, the last 5 key sub-criteria are "Human resources management" (0.0118), "Project management" (0.0132), "Innovation of process technology" (0.0176), "Competence of financial operation" (0.0237) and "Market share" $(0.0286)$. The empirical result shown that the weight ranking of sub-criteria in different clusters excluding the existing clustering effect. In other words, there were no specific clusters of criteria with high or low weighted points in the midst of weight ranking of eighteen integral sub-criteria. Several phenomena are worthy to discuss in particular from the weight ranking of sub-criteria. The highest weighted point A1, profitability, stands for a significant and evident fact. As far as not only the biotech and pharmaceutical operations but also most of enterprises are concerned, the enterprise profitability is made use of as effective indicator to evaluate the operating performance. The indicator of profitability directly enables to appear the competence of funds appreciation in the enterprise as well as maximize the stakeholder's rights and interests as the outcome. As a result, the biotech and pharmaceutical corporations reach the optimum output and destined goal or the best level operation service. C2, efficiency of production and cost with the secondary highest weighted points, showed the enterprise possesses competitive advantages more than other enterprises in the similar industry by means of enhancing the production and cost efficiency. The third place is B4, innovative products and R\&D strategies. The biotech and pharmaceutical corporations are bound to tolerant lengthier period of $R \& D$ of product and technology and input of $R \& D$ resources with more risks, different from electronic and information technology corporations. Accordingly, precise, practical and feasible $\mathrm{R} \& \mathrm{D}$ strategies of new product and technology are above all significant. The enterprise has change to acquire more profits and goodwill by enhancement of technology, product and service. $\mathrm{C} 1$, quality management and cost control, the fourth place. Most biotech and pharmaceutical corporations are part of standard production and manufacturing industry. For this reason, quality management and cost control urge the enterprise on enhancing its operating management and production. The fifth place of weight ranking of sub-criteria is D4, the operation strategy and business mode, the more traditional competitive condition in the enterprise, but still the most essential competitive source in the most enterprises so far.

Otherwise, the weight ranking of sub-criteria including in all criteria is at the end of 5 rankings, which appeared the data acquired by expert questionnaire is able to gain precise sub-criteria weighted points through FANP calculating is noticeable. Furthermore, the weighted points of 18 sub-criteria appear even descending trend seemingly. The accumulated weighted point of sub-criteria of top 5 rankings is $50.32 \%$ so that these five sub-criteria named key elements as building the mechanism of operating performance evaluation in Taiwan biotech and pharmaceutical corporations. Likewise, the accumulation of weights of other 13 sub-criteria is under $50 \%$. Apparently, the experts tend to evaluate the operating performance of enterprise through the real results rather than the sort of 'input' indicator such as the input of $R \& D$ funds, innovative competence and management as the significant basis to evaluate the performance. The main reason consists in the input of resources Taiwan corporations possess is even less compared with biotech and pharmaceutical corporations in advanced countries. These resources incorporate talent personnel in the industry, $R \& D$ resources, advanced industrial environment, government support, fund scale and managerial experience. Moreover, Taiwan biotech and pharmaceutical corporations are bound to encounter the issues are lengthy period of product and technology, high-rate failure and the risk brought by international food and drugs acts, which enable the experts in this industry to analyze the indicator of performance evaluation and weighting with more practical attitude. Hence, the empirical analysis at this stage appeared the researcher is suppose to pay attention to the fact of industry existing while analyzing the operating performance in Taiwan biotech and pharmaceutical corporations. Besides, the researcher is proposed to focus on the practical output yield rather than the input resources in the enterprise. 
Table 5. Final weights by FNAP analysis

\begin{tabular}{lll}
\hline Rank & Criteria & Weight \\
\hline 1 & Product and technology R\&D (B) & 0.3841 \\
2 & Financial performance (A) & 0.2767 \\
3 & Production and quality management (C) & 0.2195 \\
4 & Organization characteristics and operation management (D) 0.1197 \\
Rank & Sub-Criteria & Weight \\
1 & Profitability (A1) & 0.1274 \\
2 & Efficiency of production and cost (C2) & 0.1145 \\
3 & Innovative products and R\&D strategies (B4) & 0.0941 \\
4 & Quality management and cost control (C1) & 0.0837 \\
5 & Operation strategy and business mode (D4) & 0.0835 \\
6 & Group scale (D3) & 0.0733 \\
7 & Patent and intellectual property right (B3) & 0.0684 \\
8 & The enterprise market value (A2) & 0.0672 \\
9 & Marketing strategy and expenditure application (D1) & 0.0527 \\
10 & The competence of R\&D team (B2) & 0.0454 \\
11 & Systems of production and operation management (C3) & 0.0343 \\
12 & The enterprise investment performance (A4) & 0.0317 \\
13 & R\&D expenditure rate (B1) & 0.0290 \\
14 & Market share (D2) & 0.0286 \\
15 & Competence of financial operation (A3) & 0.0237 \\
16 & Innovation of process technology (C4) & 0.0176 \\
17 & Project management (B5) & 0.0132 \\
18 & Human resources management (D5) & 0.0118 \\
\hline & & \\
\hline
\end{tabular}

At the last phase of the study, the top 10 listed Taiwan biotech and pharmaceutical corporations took the conglomerate revenue as the empirical research sample on this study. Based on the size of scale of conglomerate revenue, these corporations are Johnson Health Tech, Grape King Bio, YungShin, Excelsior Medical, China Chemical, ScinoPharm Taiwan, Standard Chemical, Sinphar Pharm, Formosa Laboratories, and Apex Medical, Johnson Health Tech, Excelsior Medical and Apex Medical of which are selling medical appliances while others are pharmaceutical corporations. Next, 15 experts are invited to apply performance evaluation table to aim at the operating performance evaluating consecutively. Considering the exclusive fluctuate characteristic of industry, the empirical period of operating performance evaluation was from 2013 to 2014. Each expert aimed at 10 corporations evaluating through each sub-criteria. The points were given from 0 to 100 . The higher points, the better performance. The points of each sub-criterion obtained by multiplying weight of each sub-criterion at Table 5 and expert's real evaluation, and the total points were the sum of all sub-criteria points. The Table 6 showed as all sub-criteria points in 10 corporations and the ranking of total points.

Table 6. The points of all sub-criteria and the ranking of total points in top 10 of conglomerate revenue in Taiwan biotech corporations

\begin{tabular}{lllllll}
\hline \multirow{2}{*}{ Criteria } & $\begin{array}{l}\text { Sub-Criteria } \\
\text { (Weight) }\end{array}$ & Johnson HealthTech & Grape King Bio & YungShin & Excelsior Medical China Chemical \\
\cline { 3 - 6 } & A1 (0.1274) & 9.1728 & 9.0879 & 8.2385 & 5.2659 & 5.6905 \\
A & A2 (0.0672) & 4.7040 & 4.4352 & 3.8976 & 2.5984 & 2.6432 \\
& A3 (0.0237) & 2.0540 & 1.8170 & 1.3588 & 1.3746 & 1.1218 \\
& A4 (0.0317) & 2.0711 & 2.7473 & 1.9654 & 1.3314 & 1.6061 \\
\hline \multirow{4}{*}{ B } & B1 (0.0290) & 1.5660 & 1.2567 & 2.1267 & 0.5413 & 2.1847 \\
& B2 (0.0454) & 3.7228 & 2.1187 & 2.6937 & 2.3305 & 2.3608 \\
& B3 (0.0684) & 5.6088 & 2.7816 & 3.5568 & 4.8792 & 3.2376 \\
& B4 (0.0941) & 7.6535 & 5.2069 & 5.0814 & 3.8895 & 4.7677 \\
& B5 (0.0132) & 1.0736 & 0.8976 & 0.7128 & 1.0208 & 0.6952 \\
\hline
\end{tabular}




\begin{tabular}{|c|c|c|c|c|c|c|}
\hline \multirow{4}{*}{$\mathrm{C}$} & C1 (0.0837) & 4.8546 & 5.9706 & 5.1336 & 4.7430 & 4.6872 \\
\hline & C2 (0.1145) & 8.0913 & 10.0760 & 7.3280 & 4.8853 & 5.9540 \\
\hline & C3 (0.0343) & 1.5778 & 1.4635 & 2.0808 & 2.3553 & 2.4696 \\
\hline & C4 (0.0176) & 0.9269 & 0.7627 & 1.0091 & 0.9973 & 0.8448 \\
\hline \multirow{5}{*}{$\mathrm{D}$} & D1 (0.0527) & 2.8458 & 2.5296 & 3.1269 & 4.2862 & 3.5133 \\
\hline & D2 (0.0286) & 2.1736 & 2.0973 & 2.0401 & 1.9829 & 1.9257 \\
\hline & D3 (0.0733) & 6.0106 & 3.0297 & 4.7400 & 5.5219 & 5.1798 \\
\hline & D4 (0.0835) & 6.1233 & 4.6203 & 5.1213 & 5.4553 & 4.8430 \\
\hline & D5 (0.0118) & 0.9597 & 0.9597 & 0.8496 & 0.6215 & 0.6215 \\
\hline \multicolumn{2}{|c|}{ Total Score } & 71.1902 & 61.8582 & 61.0612 & 54.0804 & 54.3466 \\
\hline \multicolumn{2}{|c|}{ Rank } & 1 & 3 & 4 & 10 & 7 \\
\hline
\end{tabular}

Table 6. The points of all sub-criteria and the ranking of total points in top 10 of conglomerate revenue in Taiwan biotech corporations (continued)

\begin{tabular}{|c|c|c|c|c|c|c|c|}
\hline \multirow[b]{2}{*}{ Criteria } & \multirow{2}{*}{$\begin{array}{c}\text { Sub-Criteria } \\
\text { (Weight) }\end{array}$} & \multicolumn{6}{|c|}{ Company } \\
\hline & & $\begin{array}{l}\text { ScinoPharm } \\
\text { Taiwan }\end{array}$ & $\begin{array}{l}\text { Standard } \\
\text { Chemical }\end{array}$ & Sinphar Pharm & $\begin{array}{l}\text { Formosa } \\
\text { Laboratories }\end{array}$ & Apex Medical & Mean \\
\hline \multirow{4}{*}{ A } & A1 (0.1274) & 4.5015 & 7.1344 & 4.5864 & 6.7947 & 7.7289 & 6.8201 \\
\hline & A $2(0.0672)$ & 5.7344 & 2.7328 & 2.7776 & 2.5536 & 2.5088 & 3.4586 \\
\hline & A3 (0.0237) & 0.9480 & 1.2324 & 1.0902 & 1.4378 & 1.2640 & 1.3699 \\
\hline & A4 (0.0317) & 1.2891 & 1.8386 & 1.3737 & 1.4582 & 2.3035 & 1.7984 \\
\hline \multirow{5}{*}{ B } & B1 (0.0290) & 2.3393 & 2.3393 & 2.4167 & 2.2813 & 1.8947 & 1.8947 \\
\hline & B2 (0.0454) & 2.6635 & 3.0872 & 3.5109 & 2.6937 & 3.9044 & 2.9086 \\
\hline & B3 (0.0684) & 3.1920 & 4.9248 & 5.1528 & 3.0096 & 5.8824 & 4.2226 \\
\hline & B4 (0.0941) & 4.8305 & 5.9597 & 5.5833 & 4.8305 & 7.9044 & 5.5456 \\
\hline & B5 (0.0132) & 0.9680 & 0.6072 & 0.6512 & 0.9064 & 0.6512 & 0.8184 \\
\hline \multirow{4}{*}{$\mathrm{C}$} & C1 (0.0837) & 5.1336 & 5.0220 & 4.6872 & 4.9662 & 4.9104 & 5.0108 \\
\hline & C2 (0.1145) & 4.7327 & 6.7937 & 5.0380 & 5.4197 & 8.5493 & 6.6868 \\
\hline & C3 (0.0343) & 2.4925 & 2.2181 & 2.4239 & 2.2638 & 1.4863 & 2.0832 \\
\hline & C4 (0.0176) & 0.9387 & 1.3611 & 1.2555 & 1.1264 & 1.2437 & 1.0466 \\
\hline \multirow{5}{*}{$\mathrm{D}$} & D1 (0.0527) & 3.5133 & 3.0917 & 2.9512 & 4.0755 & 2.9161 & 3.2850 \\
\hline & D2 (0.0286) & 1.9067 & 1.7923 & 1.6016 & 1.5635 & 1.4872 & 1.8571 \\
\hline & D3 (0.0733) & 5.7174 & 3.0297 & 3.7139 & 3.2252 & 1.7103 & 4.1879 \\
\hline & D4 (0.0835) & 5.3996 & 4.9543 & 4.6203 & 4.7873 & 5.2326 & 5.1158 \\
\hline & D5 (0.0118) & 0.8417 & 0.7552 & 0.7473 & 0.6923 & 0.6215 & 0.7670 \\
\hline \multicolumn{2}{|l|}{ Total Score } & 57.1424 & 58.8744 & 54.1816 & 54.0856 & 62.1998 & 58.9020 \\
\hline \multicolumn{2}{|l|}{ Rank } & 6 & 5 & 8 & 9 & 2 & \\
\hline
\end{tabular}

As Table 6 appeared, the top 10 rankings and total points of operating performance in Taiwan biotech and pharmaceutical incorporations obtained are Johnson Health Tech (71.1902), Apex Medical (62.1998), Grape King Bio (61.8582), YungShin (61.0612), Standard Chemical (58.8744), ScinoPharm Taiwan (57.1424), China Chemical (54.3466), Sinphar Pharm (54.1816), Formosa Laboratories (54.0856) and Excelsior Medical (54.0804) in sequence. Two corporations with the highest points, Johnson Health Tech and Apex Medical, are the manufactures engaged in medical appliances designing, producing, marketing and importing and exporting. Grape King Bio and YungShin Global Holding are the old-brand enterprises with the highest points of operating performance. According to the experts' evaluation, the total points of weighted average from 2013-2014 in 10 Taiwan biotech and pharmaceutical corporations as whole samples is 58.9020. Only the weighted average points of Johnson Health Tech is over 71 and obtained the grade of 'Quite good'. The weighted average points in Apex Medical, Grape King Bio, YungShin, Standard Chemical and ScinoPharm Taiwan are between 57-70, the grade evaluated as 'Slightly good'. In addition, the weighted average points in China Chemical, Sinphar Pharm, Formosa Laboratories and Excelsior Medical are lower than 55, the grade evaluated as 'Average'.

These analyzed empirical results shown the enterprise operating performance in Taiwan biotech and pharmaceutical corporations fell at 'Slightly good' as a whole. Also, the operating performance in partial biotech corporations engaging in medical appliances is higher than pharmaceutical corporations, which appeared the 
complexity and diversity as the characteristics in Taiwan biotech and pharmaceutical corporations. These enterprises possess high ambitious of innovation and R\&D as well as acquire plenty of outcomes. The integration of different subjects, such as the biotech, medical, computer science and technology, control engineering and electrical engineering is involved in R\&D of medical technology. The industry development in different fields furnishes the nutrients for R\&D of medical technology. Meanwhile, undeniable, the funds and resources required in order to develop medical technology in Taiwan biotech corporations engaged in medical appliances are unable to compare with international enterprises. Nevertheless, these corporations own their ways to take places in the chain of global medical appliances industry. Compared with other biotech corporations, the input of funds of R\&D, manpower and all sorts of resources in Taiwan pharmaceutical corporations are obviously unable to reflect the profitability and operating performance of enterprise. The development of new drugs is the investment with higher risk in particular. In addition, the pharmaceutical corporations encounter more limitations from official policies and acts. Supposing the pharmaceutical corporations only rely on production and selling Generic Drugs as the main business, as well as the profitability of which is probably compromised. However, as far as the current stage concerned, the main financial resource is from traditional operating mode in the pharmaceutical corporations with $R \& D$ of new drugs, which is undebatable fact. Additionally, the top 5 rankings of average weighted points of each sub-criterion in all samples are "A1" (6.8201), "C2" (6.6868), "B4" (5.5456), "D4" (5.1158) and "C1" (5.0108) in sequence. The average weighted points of top 5 sub-criteria took up $49.54 \%$ of average total points so that the result is similar with the result of weight raking in substance.

\section{Conclusion}

The high proportion of $R \& D$, lengthy period of R\&D, high obstacle of industry entry as well as costly R\&D expenses occur in Taiwan biotech and pharmaceutical corporations. Encountering industry environment with complete competition, these corporations are bound to value channels and marketing function, emphasize on the management of intellectual property to make use of resources effectively and promote the rewards of investment. Accordingly, how to precisely evaluate the performance with scientificization and datumization is becoming a significant and new issue. On the former related studies of operating performance in Taiwan biotech and pharmaceutical corporations, the researchers mainly made use of DEA and SFA. Yet, these approaches evaluate less variables of enterprise operation unable to present entirely all aspects of enterprise operation. As the result, one innovative thinking and approach is given on this study, which modified Delphi approach, ISM and FANP associate with performance evaluation table to build completely evaluation mode of operating performance in Taiwan biotech and pharmaceutical corporations.

The result of research appeared the significant sequence of criteria is "Product and technology R\&D", "Financial performance", "Production and quality management" and "Organization characteristics and operation management". The irreplaceable competitive advantages in the enterprise is transformed by the R\&D resources and of products and technology invested by the enterprise and specific results acquired by R\&D team, the result of which complies with the current situation in Taiwan biotech and pharmaceutical corporations. In the midst of 18 sub-criteria, the top 5 key sub-criteria influence performance evaluation of corporation operation in biotech and pharmaceutical corporations in Taiwan are "Profitability", "Efficiency of production and cost", "Innovative products and R\&D strategies", "Quality management and cost control" and "Operation strategy and business mode". Comparatively speaking, the last 5 key sub-criteria are "Human resources management", "Project management", "Innovation of process technology", "Competence of financial operation" and "Market share". The accumulated weighted point of sub-criteria of top 5 rankings is $50.32 \%$ so that these five sub-criteria named key elements as building the mechanism of operating performance evaluation in Taiwan biotech and pharmaceutical corporations. Apparently, the experts tend to evaluate the operating performance of enterprise through the real results rather than the sort of 'input' indicator such as the input of R\&D funds, innovative competence and all managerial skills as the significant basis to evaluate the performance.

The top 10 of conglomerate revenue in listed companies taken as the sample of empirical research on this study, including 3 companies with medical appliances and 7 pharmaceutical corporations. The empirical period is from 2013 to 2014 of operating performance evaluation. Two corporations with the highest points, Johnson Health Tech and Apex Medical, are the manufactures engaged in medical appliances designing, producing, marketing and importing and exporting. Grape King Bio and YungShin Global Holding are the old-brand enterprises with the highest points of operating performance. According to the experts' evaluation, the total point of weighted average is 58.9020 of whole sample in complete period in all enterprises, which fell at the grade of 'Slightly good' as a whole. Only Johnson Health Tech obtained the grade of 'Quite good' over 71, weighted average points. 
The input of funds of R\&D, manpower and all sorts of resources in Taiwan pharmaceutical corporations are obviously unable to reflect the profitability and operating performance of enterprise. Compared with other biotech corporations, the input of funds of R\&D, manpower and all sorts of resources in Taiwan pharmaceutical corporations are obviously unable to reflect the profitability and operating performance of enterprise. The development of new drugs is the investment with higher risk in particular. In addition, the pharmaceutical corporations encounter more limitations from official policies and acts.

The evaluated mode of operating performance in Taiwan biotech and pharmaceutical corporations was built precisely and completely with practical attitude on this study. The related results accord with the real situation in the industry. The result of this study is able to be a significant basis as the policies drawn up by government, operating performance evaluated by the enterprise and investment target measured by the investors.

\section{References}

Aaker, D. A. (1998). Strategic market management (5th ed.). New York, NY: John Wiley \& Sons.

Amato, L., \& Wilder, R. (1990). Firm and industry effects in industrial economics. Southern Economic Journal, 57, 93-105. http://dx.doi.org/10.2307/1060480

Becker, G. S. (1964). Human capital: A theoretical and empirical analysis, with special reference to education. New York: National Bureau of Economic Research.

Benjamin, B. A., \& Podolny, J. M. (1999). Status, quality and social order in the California wine industry. Administrative Science Quarterly, 44(3), 563-589. http://dx.doi.org/10.2307/2666962

Bontis, N., Keow, W. C. C., \& Richardson, S. (2000). Intellectual capital and business performance in Malaysian industries. Journal of Intellectual Capital, 1(1), 85-100. http://dx.doi.org/10.1108/14691930010324188

Bosworth, D., \& Rogers, M. (2001). Market value, R\&D and intellectual property: An empirical analysis of large Australian firms. Economic Record, 77(239), 323-337. http://dx.doi.org/10.1111/1475-4932.t01-1-00026

Buckley, J. J. (1985). Fuzzy hierarchical analysis. Fuzzy Sets and Systems, 17, 233-247. http://dx.doi.org/10.1016/0165-0114(85)90090-9

Charan, R. (2004). Profitable growth is everyone's business: 10 tools you can use Monday morning. New York, NY: Crown Business.

Chen, C. M., Sheng, T. C., \& Yang, Y. L. (2014). Cost efficiency analysis of Taiwan biotech and pharmaceutical industry: The application of stochastic meta frontier model. International Journal of Economics and Finance, 6(11), 131-141. http://dx.doi.org/10.5539/ijef.v6n11p131

Chen, C. M., Sheng, T. C., \& Yang, Y. L. (2015). Market structure, government shareholding and cost efficiency in Taiwan's biotech industry. Journal of Economics and Management, 11(1), 69-100.

Chen, M. F., Hu, J. L., \& Ding, C. G. (2005). Efficiency and productivity of Taiwan's biotech industry. International Journal of Biotechnology, 7, 307-322. http://dx.doi.org/10.1504/IJBT.2005.007632

Chenhall, R. H. (1997). Reliance on manufacturing perfor-mance measures, total quality management and orga-nizational performance. Management Accounting Research, 8, 187-206. http://dx.doi.org/10.1006/mare.1996.0038

Chenhall, R. H., \& Langfield-Smith, K. (1998). The relationship between strategic priorities, management techniques and management accounting: An empirical investigation using a systems approach. Accounting, Organizations and Society, 23(3), 243-264. http://dx.doi.org/10.1016/S0361-3682(97)00024-X

Chiu, Y. H., Chen, Y. C., \& Tsao, C. L. (2005). The estimation of Taiwan biotechnology industry's productivity and efficiency. Tsing Hua Journal of Law and Technology Policy, 2, 93-120.

Chiu, Y. H., Hu, J. L., \& Tsao, C. L. (2003). Cost efficiency of biotech firms in Taiwan. Agriculture and Economics, 31, 55-78.

Corry, P., \& Kozan, E. (2004). Mete-heuristics for a complex push-pull production system. Journal of Intelligent Manufacturing, 15, 381-393. http://dx.doi.org/10.1023/B:JIMS.0000026575.95980.c7

Cumming, D. J., \& Macintosh, J. G. (2000). The determinants of R\&D expenditures: A study of the Canadian biotechnology industry. Review of Industrial Organization, 17, 357-370. http://dx.doi.org/10.1023/A:1007864315687

Dalkey, N. C. (1969). The Delphi method: An experimental study of group opinion. Santa Monica, CA: The Rand Corporation. 
DeCarolis, D. M., \& Deeds, D. L. (1999). The impact of stocks and flows of organizational knowledge on firm performance: An empirical investigation of the biotechnology industry. Strategic Management Journal, 20, 953-968. http://dx.doi.org/10.1002/(SICI)1097-0266(199910)20:10<953::AID-SMJ59>3.0.CO;2-3

Deeds, D. L. (2001). The role of R\&D intensity, technical development and absorptive capacity in creating entrepreneurial wealth in high technology start-up. Journal of Engineering and Technology Management, 18(1), 29-47. http://dx.doi.org/10.1016/S0923-4748(00)00032-1

Delaney, J. T. (1996). Unions, human resource innovations and organizational outcomes. Advances in Industrial and Labor Relations, 7, 207-246.

Delbecq, A. L., Van de Ven, A. H., \& Gustafson, D. H. (1975). Group techniques for program planning: A guide to nominal group and Delphi processes. Chicago, NJ: Scott. Foresman and Company.

Eliasson, G. (1976). Business economic planning: Theory, practice and comparison. New York, NY: Wiley.

Fiegenbaum, A., \& Thomas, H. (1990). Strategic group and performance: The U.S. insurance industry. Strategic Management Journal, 11(3), 197-215. http://dx.doi.org/10.1002/smj.4250110303

Fullerton, R. R., \& McWatters, C. S. (2002). The role of performance measures and incentive systems in relation to the degree of JIT implementation. Accounting, Organization and Society, 27(8), 711-735. http://dx.doi.org/10.1016/S0361-3682(02)00012-0

Geraghty, J., \& Heavey, C. (2005). A review and comparison of hybrid and pull-type production control strategies. OR Spectrum, 27, 435-457. http://dx.doi.org/10.1007/s00291-005-0204-z

Griliches, Z. (1980). R\&D and the productivity slowdown. American Economic Review, 70(1), 343-348.

Griliches, Z. (1981). Market value, R\&D and patents. Economics Letters, 7(2), 183-187. http://dx.doi.org/10.1016/0165-1765(87)90114-5

Hall, B. H. (1993). The stock market valuation of R\&D investment during the 1980s. American Economic Review, 83, 259-264.

Hall, L. A., \& Bagchi-Sen, S. (2002). A study of R\&D, innovation and business performance in the Canadian biotechnology industry. Technovation, 22(4), 231-244. http://dx.doi.org/10.1016/S0166-4972(01)00016-5

Hill, K. Q., \& Fowles, J. (1975). The methodological worth of the Delphi forecasting technique. Technological Forecasting and Social Change, 7, 179-192. http://dx.doi.org/10.1016/0040-1625(75)90057-8

Hsieh, S. T., Wann, J. W., \& Lu, T. J. (2007). The innovation efficiency of agricultural biotechnology firm in Taiwan. Journal of Agricultural Economics, 82, 1-25.

Ittner, C. D., \& Larcker, D. F. (1995). Total quality management and the choice of information and reward systems. Journal of Accounting Research, 33(1), 1-34. http://dx.doi.org/10.2307/2491371

Jaffe, A. B., Trajtenberg, M., \& Fogarty, M. S. (2000). Knowledge spillover and patent citations: Evidence from a survey of inventors. American Economic Review, 9, 215-218. http://dx.doi.org/10.1257/aer.90.2.215

Jensen, M. C. (1986). Agency costs of free cash flow, corporate finance and takeovers. American Economic Review, 76, 323-329.

Jensen, M. C. (1989). Eclipse of the public corporation. Harvard Business Review, 67(5), 61-74.

Jesssop, B., \& Sum, N. L. (2000). An entrepreneurial city in action: Hong Kong's emerging strategies in and for $\begin{array}{lllll}\text { (inter) urban } & \text { competition. }\end{array}$ http://dx.doi.org/10.1080/00420980020002814

Jharkharia, S., \& Shankar, R. (2004). IT enablement of supply chains: Modeling the enablers. International $\begin{array}{llll}\text { Journal of Productivity and Performance Management, 53(8), } & \text { 700-712. }\end{array}$ http://dx.doi.org/10.1108/17410400410569116

Joseph, K., \& Richardson, V. J. (2002). Free cash flow, agency costs and the affordability method of advertising budgeting. Journal of Marketing, 66, 94-107. http://dx.doi.org/10.1509/jmkg.66.1.94.18453

Kaplan, R. S., \& Norton, D. P. (1992). The balanced scorecard: Measures that drive performance. Harvard Business Review, 70(1), 71-79.

Kaplan, R. S., \& Norton, D. P. (1993). Putting the balanced scorecard to work. Harvard Business Review, 71(5), 134-147.

Kaplan, R. S., \& Norton, D. P. (1996). The balanced scorecard: Translating into action. Boston, MA: Harvard 
Business School Press.

Kaplan, R. S., \& Norton, D. P. (2008). The execution premium: Linking strategy to operations for competitive advantage. Boston, MA: Harvard Business School Press.

Kijek, T. (2012). Innovation capital and its measurement. Journal of Entrepreneurship. Management and Innovation, 8 (4), 52-68.

Kim, W. C., \& Mauborgne, R. (2005). Blue ocean strategy: How to create uncontested market space and make the competition irrelevant. Harvard Business School Publishing Corporation.

Lai, C. S., Chiu, C. J., Yang, C. F., \& Pai, D. C. (2010). The effects of corporate social responsibility on brand performance: The mediating effect of industrial brand equity and corporate reputation. Journal of Business Ethics, 95(3), 457-469. http://dx.doi.org/10.1007/s10551-010-0433-1

Lev, B., \& Sougiannis, T. (1996). The capitalization, amortization, andvalue-relevance of R\&D. Journal of Accounting and Economics, 21, 107-138. http://dx.doi.org/10.1016/0165-4101(95)00410-6

Lev, B., \& Sougiannis, T. (1999). Penetrating the book-to-market black box: The R\&D effect. Journal of Business Finance and Accounting, 26(3/4), 419-460. http://dx.doi.org/10.1111/1468-5957.00262

Li, T. C., Wu, C. W., \& Li, M. C. (2011). An application on stochastic statistical frontier approach and decision tree: Management efficiency analysis of biotechnology industry public listed companies in Taiwan. Paper presented at 2011 Taiwan Productivity and Efficiency, Taipei, Taiwan.

Li, Y., \& Li, S. J. (2008). Analyzing TFP of Asian biotech firms: Application of stochastic frontier approach. Agricultural and Resources Economics, 5, 55-76.

Liang, S. K., Jiang, J. L., \& Lai, C. T. (2008). Effects of integrative strategies on the production efficiency of biotech firms: A data envelopment analysis. International Journal of Management, 25, 140-148.

Liou, T. S., \& Wang, M. J. (1992). Ranking fuzzy numbers with integral value. Fuzzy Sets and Systems, 50, 247-255. http://dx.doi.org/10.1016/0165-0114(92)90223-Q

Masulis, R. W. (1983). The impact of capital structure change on firm value: Some estimates. The Journal of Finance, 38(1), 107-126. http://dx.doi.org/10.1111/j.1540-6261.1983.tb03629.x

Megna, P., \& Klock, M. (1993). The impact of intangible capital on Tobin's Q in the semiconductor industry. American Economic Review, 83, 293-315.

Morbey, G. K., \& Dugal, S. S. (1992). Corporate R\&D spending during a recession. Research Technology Management, 35(4), 42-46.

Morbey, G. K., \& Reithner, R. M. (1990). How R\&D affects sales growth, productivity and profitability. Research Technology Management, 33, 11-14.

Murry, J. W., \& Hammons, J. O. (1995). Delphi: A versatile methodology for conducting qualitative research. The Review of Higher Education, 18(4), 423-436.

Osborne, A. (1998). Measuring intellectual capital: The real value of companies. The Ohio CPA Journal, 57(4), 37-38.

Pazderka, B. (1999). Patent protection and pharmaceutical R\&D spending in Canada. Canadian Public Policy, 25, 29-46. http://dx.doi.org/10.2307/3551400

Pearl, J. (2001). Intangible investment, tangible results. Sloan Management Review, 43(3), 13-14.

Ramezani, C. A., Soenen, L. A., \& Jung, A. R. (2002). Growth, corporate profitability and value creation. Financial Analysts Journal, 58(6), 56-66. http://dx.doi.org/10.2469/faj.v58.n6.2486

Ravi, V., Shankar, R., \& Tiwari, M. K. (2005). Productivity improvement of a computer hardware supply chain. International Journal of Productivity and Performance Management, 54(4), 239-255. http://dx.doi.org/10.1108/17410400510593802

Roberts, E. B., \& Mizouchi, R. (1989). Inter-firm technological collaboration: The case of Japanese biotechnology. International Journal of Technology Management, 4(1), 43-61.

Roberts, P. W., \& Dowling, G. R. (2002). Corporate reputation and sustained superior financial performance. Strategic Management Journal, 23(12), 1077-1093. http://dx.doi.org/10.1002/smj.274

Rowe, G., \& Wright, G. (1999). The Delphi technique as a forecasting tool: Issues and analysis. International Journal of Forecasting, 15, 353-375. http://dx.doi.org/10.1016/S0169-2070(99)00018-7 
Saaty, T. L. (1980). The analytic hierarchy process. New York, NY: McGraw- Hill.

Saaty, T. L. (1996). Decision making with dependence and feedback: The analytic network process. Pittsburgh, PA: RWS Publications.

Saxton, T., \& Dollinger, M. (2004). Target reputation and appropriability: Picking and deploying resources in acquisitions. Journal of Management, 30(1), 123-147. http://dx.doi.org/10.1016/j.jm.2003.01.006

Schumpeter, J. A. (1950). Capitalism, socialism and democracy (3rd ed.). New York, NY: Harper and Row.

Senecal, S., Kalczynski, P. J., \& Nantel, J. (2005). Consumers' decision-making process and theironline shopping behavior: A click stream analysis. Journal of Business Research, 58(11), 1599-1608. http://dx.doi.org/10.1016/j.jbusres.2004.06.003

Sheng, T. C. (2009). An empirical investigation of the cost efficiency factors and economies/diseconomies of scale effects in Taiwan's biotech-pharmaceutical industry: A stochastic frontier analysis (SFA) approach (Unpublished doctoral dissertation). Northwestern Polytechnic University, California, USA.

Sheng, T. C., Liu, K. P., \& Yang, Y. L. (2012). Estimating the three-stage cost malmquist productivity index in the Taiwan biotech and biopharmaceutical industry. Journal of Modern Accounting and Auditing, 8(5), 679-687.

Skinner, W. (1969). Manufacturing-missing link in corporate strategy. Harvard Business Review, 47(3), 136-145.

Sougiannis, T. (1994). The accounting based valuation of corporate R\&D. The Accounting Review, 69(1), 44-68.

Spearm, M. L., \& Zazanis, M. A. (1992). Push and pull production systems: Issues and comparisons. Operations Research, 40(3), 521-532. http://dx.doi.org/10.1287/opre.40.3.521

Stewart, T. R. (1987). The Delphi technique and judgmental forecasting. Climatic Change, 11, 97-113. http://dx.doi.org/10.1007/BF00138797

Tazki, E., \& Amagsa, M. (1997). Structural modeling in a class of systems using fuzzy sets theory. Fuzzy Sets and Systems, 2(1), 87-103. http://dx.doi.org/10.1016/0165-0114(79)90018-6

Tseng, C. Y., \& Goo, Y. J. J. (2005). Intellectual capital and corporate value in an emerging economy: Empirical study of Taiwanese manufacturers. $R \& D$ Management, $35(2), \quad$ 187-201. http://dx.doi.org/10.1111/j.1467-9310.2005.00382.x

Turban, D. B., \& Cable, D. M. (2003). Firm reputation and applicant pool characteristics. Journal of Organizational Behavior, 24(6), 733-751. http://dx.doi.org/10.1002/job.215

Van der Stede, W. A., Chow, C. W., \& Lin, T. W. (2006). Strategy, choice of performance measures and $\begin{array}{llll}\text { performance. Behavioral Research in Accounting, 18, } & \text { 185-205. }\end{array}$ http://dx.doi.org/10.2308/bria.2006.18.1.185

Van Laarhoven, P. J. M., \& Pedrycz, W. (1983). A fuzzy extension of Saaty's priority theory. Fuzzy Sets and Systems, 11, 229-241. http://dx.doi.org/10.1016/S0165-0114(83)80082-7

Venkatraman, N., \& Ramanujam, V. (1986). Measurement of business performance in strategy research: A comparison of approaches. Academy of Management Review, 11(4), 801-814. http://dx.doi.org/10.5465/AMR.1986.4283976

Warfield, J. N. (1973a). On arranging elements of a hierarchy in graphic form. IEEE Transactions on Systems, Man, and Cybernetics, 3(2), 121-132. http://dx.doi.org/10.1109/TSMC.1973.5408493

Warfield, J. N. (1973b). Binary matrices in system modeling. IEEE Transactions on Systems, Man, and Cybernetics, 3(5), 441-449. http://dx.doi.org/10.1109/TSMC.1973.4309270

Warfield, J. N. (1974). Toward interpretation of complex structural models. IEEE Transactions on Systems, Man, and Cybernetics, SMC4(5), 405-417. http://dx.doi.org/10.1109/TSMC.1974.4309336

Warfield, J. N. (1975). An introduction to the application of interpretive structural modeling. Proceedings of the IEEE, 63(3), 397-404. http://dx.doi.org/10.1109/PROC.1975.9765

Warfield, J. N. (1976). Societal systems: Planning, policy and complexity. New York, NY: Wiley.

Warfield, J. N. (1990). A science of generic design: Managing complexity through system design. Salinas, CA: Intersystems.

White, R. E., \& Ruch, W. A. (1990). The composition and scope of JIT. Operations Management Review, 7(3-4), 9-18. 
Williamson, O. E. (1979). Transaction cost economics: The governance of contractual relations. Journal of Law and Economics, 22, 233-261. http://dx.doi.org/10.1086/466942

Wright, P., Ferris, S. P., Hiller, J. S., \& Kroll, M. (1995). Competitiveness through management of diversity: Effects on stock price valuation. Academy of Management Journal, 38(1), 272-287. http://dx.doi.org/10.2307/256736

Wu, C. R., Chang, C. W., \& Lin, H. L. (2008). A fuzzy ANP-based approach to evaluate medical organizational performance. International Journal of Information and Management Sciences, 19(1), 53-74.

Yang, Y. L., Sheng, T. C., \& Huang, M. H. (2010). Estimating the cost malmquist productivity index in the Taiwan biotech and biopharmaceutical industry. Taiwan Journal of Applied Economics, 2009 Special Issue, 59-85.

Yeh, T. L., Chen, T. Y., \& Chen, C. Y. (2007). On capital structure, ownership and cost efficiency: A case study from Taiwan's biotechnology industry. Taiwan Banking \& Finance Quarterly, 8(3), 45-64.

\section{Copyrights}

Copyright for this article is retained by the author(s), with first publication rights granted to the journal.

This is an open-access article distributed under the terms and conditions of the Creative Commons Attribution license (http://creativecommons.org/licenses/by/3.0/). 